Article

\title{
Evaluating the Road-Bioretention Strip System from a Hydraulic Perspective-Case Studies
}

\author{
Xiaoning $\mathrm{Li}^{1}$, Xing Fang ${ }^{1,2, *}$, Yongwei Gong ${ }^{2}$, Junqi $\mathrm{Li}^{2}$, Jianlong Wang ${ }^{2}$, Gang Chen ${ }^{3} \mathbb{C}$ and \\ Ming-Han $\mathrm{Li}^{4}$ \\ 1 Department of Civil Engineering, Auburn University, Auburn, AL 36849-5337, USA; xz10055@auburn.edu \\ 2 Key Laboratory of Urban Stormwater System and Water Environment, Ministry of Education, Beijing \\ University of Civil Engineering and Architecture, Beijing 100044, China; gongyongwei@bucea.edu.cn (Y.G.); \\ lijunqi@bucea.edu.cn (J.L.); wjl_xt@163.com (J.W.) \\ 3 College of Hydrology and Water Resources, Hohai University, No. 1 Xikang Road, Nanjing 210098, China; \\ gangchen@hhu.edu.cn \\ 4 School of Planning, Design and Construction, Michigan State University, East Lansing, MI 48824, USA; \\ minghan@msu.edu \\ * $\quad$ Correspondence: xing.fang@auburn.edu; Tel.: +1-334-844-8778; Fax: +1-334-844-6290
}

Received: 17 October 2018; Accepted: 29 November 2018; Published: 4 December 2018

\begin{abstract}
The two-dimensional overland flow simulation program, FullSWOF_2D, was revised to include submodules of determining infiltration by zones $(Z)$ and grate-inlet $(G)$ drainage from a $2 \mathrm{D}$ surface to a 1D pipe flow. The updated program, FullSWOF-ZG, was used to evaluate the performance of a road-bioretention strip (RBS) system and explore/understand key parameters of continuous RBS design. The program was validated using eight pervious surfaces under simulated rainfall events and tested with 20 experimental cases of a locally depressed curb inlet. The mean difference of simulated interception efficiencies $(36.6 \%-86.0 \%)$ and observed interception efficiencies $(34.8 \%-84.0 \%)$ of the curb inlet was $3.5 \%$, which proves the program predicts the curb-inlet interception efficiency accurately. The 20 road-only and 20 RBS modeling cases were designed and modeled using the FullSWOF-ZG program. These case studies have different road lengths, curb inlet lengths, longitudinal slopes, cross slopes, bioretention-overflow inlet heights, and bioretention soil infiltration parameters. Only $34.6 \%-48.4 \%$ of the total runoff volume is intercepted by the RBS's curb inlet under heavy rainfall $(250 \mathrm{~mm} / \mathrm{h})$ and the remaining part of the runoff flows downstream along the road, which may cause local inundation and become a safety hazard. The curb inlet becomes the bottleneck of the RBS system that could impede the runoff flowing into the bioretention strip for detention and infiltration to improve the stormwater quality.
\end{abstract}

Keywords: road-bioretention strip; hydraulic design calculation; curb inlet; FullSWOF_2D; sponge city paradigm; low impact development; stormwater management

\section{Introduction}

Over the past 40 years to 2016, China's urban population rose from $17.6 \%$ in 1977 to $57.4 \%$ of its total population, which led to rapid urbanization, and this trend will keep increasing by $1 \%$ per year to reach approximately $60 \%$ by $2020[1,2]$. Consequently, different city syndromes, such as water shortage, water pollution, flood inundation, and ecologic deterioration, have happened frequently over the past decades, causing huge economic loss and becoming large obstacles to sustainable development in China [1,3] as well as in other parts of the world [4-6]. The national New-type Urbanization Plan (2014-2020) was launched in March 2014 by the Chinese central government and emphasized environmental-friendly and sustainable urbanization approaches as an important component of the 
blueprint [7]. In order to endorse the sustainable urbanization plan, the Sponge City (SPC, a summary of definitions or descriptions of all acronyms and symbols used in the paper is given in Appendix A) paradigm based on green/gray stormwater management infrastructure integration was announced in 2013 as a relief countermeasure to city syndromes in China [8-10].

An important component of the low impact development (LID), bioretention best management practice (BMP) in Prince George's County, Maryland [11] is a stormwater quantity and quality control practice that facilitates decreasing surface runoff, increasing groundwater recharge, and treating various pollutants through a variety of processes [12-14]. Many bioretention cells were used in LID practices and studied by many researchers in the past. These bioretention cells receive the runoff from different small drainage areas, such as parking lots and a few urban buildings. Bioretention BMP has been applied to diverse sites, including residential gardens [15], parking lots [16-18], and along urban roads and highways [19-23]. Typical bioretention design includes a vegetation layer (ponding area), a soil layer (organic or mulch layer plus planting soil), a storage layer filled with gravels, an overflow inlet, and an optional underdrain (perforated pipe) (Figure 1). When saturated hydraulic conductivity is less than $13 \mathrm{~mm} / \mathrm{h}$, an underdrain system for infiltrated water is required, which flows to the outfall point [14]. As an important and typical practice, a continuous road-bioretention strip (RBS) (Figures 1 and 2), which combines green/gray infrastructures to facilitate road runoff control through infiltration and storage as well as decreasing road local flood inundation risk, is widely used in the pilot SPC construction [9]. A continuous RBS is built along an urban road or street over s relatively long distance and could be separated into several cells/units by check dams (berms) when the longitudinal slope is large enough. The slope and distance between two check dams control the ponding depth and length in the RBS. When the slope is small, the RBS could be one single elongated cell containing tree planters (Figure 2).

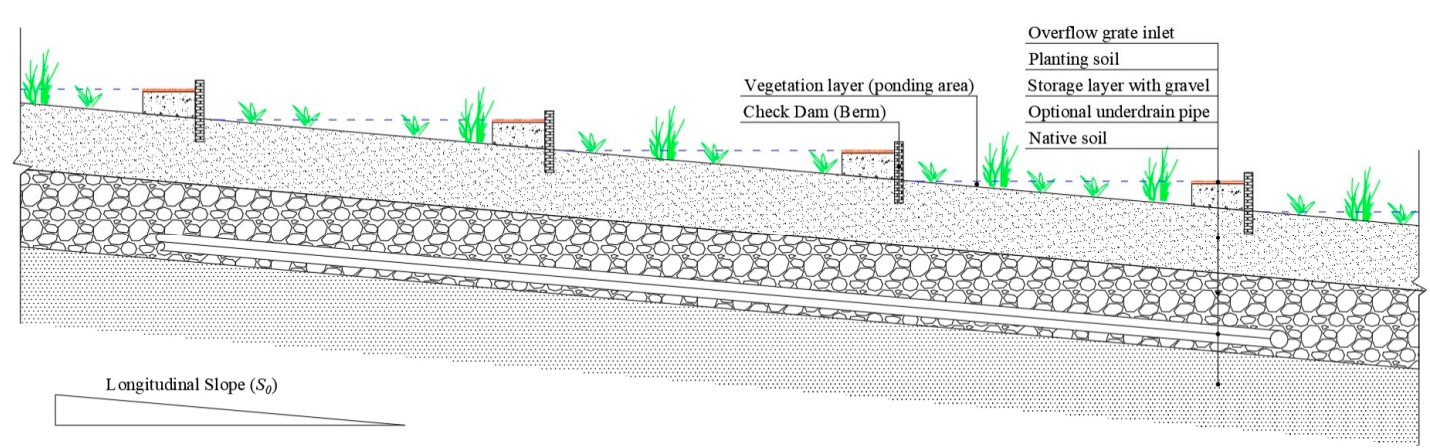

Figure 1. Schematic diagram of a continuous road-bioretention strip.

Figure 2 shows four RBS projects in four SPC pilot cities, indicating that road-bioretention systems are widely built in China. Figure 2a is a continuous RBS built in the Beijing Economic-Technological Development Area. The vegetation in the bioretention strip is very dense and its vegetation volume is a large fraction of the bioretention ponding volume. The concern is that dense vegetation may affect the ponding process of runoff. Figure $2 b, c$ present two projects built in Shenzhen, Guangdong province and Jinan, Shandong province, respectively. The bioretention strips with tree planters were constructed on the right-of-way. Figure $2 \mathrm{~d}$ presents a road-bioretention project in Ningbo, Zhejiang province; its bioretention curb inlet was designed mainly from the landscape perspective rather than for the flow intercepting function purpose. Different from right-of-way bioretention cells constructed in the USA, road-bioretention projects in SPC pilot cities are always very long along the roadside and are combined with tree planters [9]. Different types of curb inlets (outlined by red rectangles in Figure 2) have been used in different projects while no guidance for designing curb inlets of the RBS systems is available. These RBS curb inlets were designed from the landscape and safety perspective and based on experience rather than research findings on RBS' curb inlet interception efficiencies. Continuous RBS performance on intercepting road runoff and reducing local flooding under different 
rainfall events or upstream inflows is still unclear. Key design parameters of continuous RBS also need to be explored and determined.

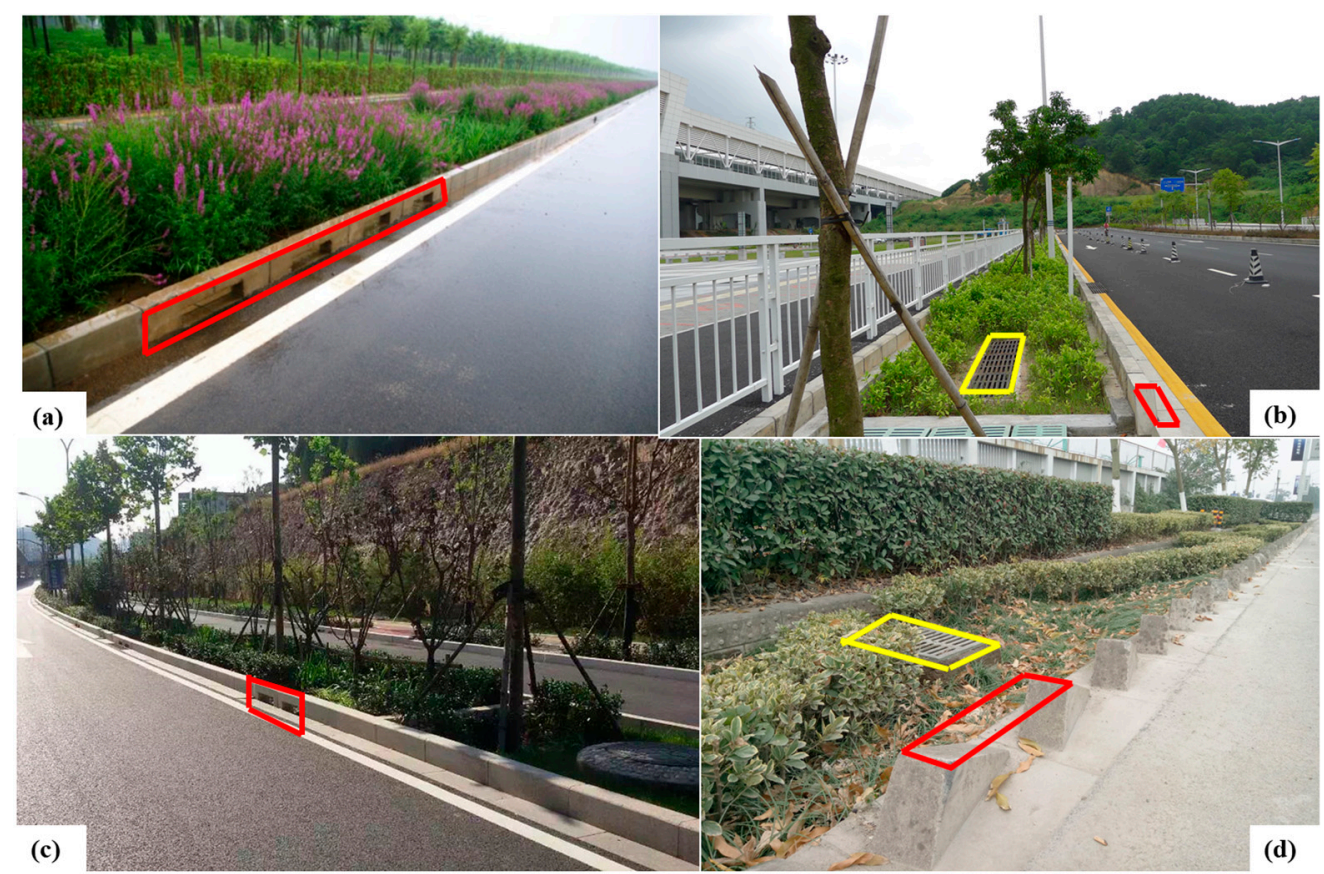

Figure 2. Continuous road-bioretention strip in (a) Beijing (curb inlet length $L_{c i}=0.5 \mathrm{~m}$ ) taken by Yongwei Gong, (b) Shenzhen $\left(L_{c i}=0.4 \mathrm{~m}\right)$ taken by Yongwei Gong, (c) Jinan $\left(L_{c i}=0.4 \mathrm{~m}\right)$ taken by Xiaoning Li, and $(\mathbf{d})$ Ningbo $\left(L_{c i}=0.3 \mathrm{~m}\right)$ taken by Jianlong Wang. Red boxes show curb inlets and yellow boxes show overflow grate inlets in the bioretention cells.

Normally, each RBS cell has an overflow grate inlet at the downstream end and near the berm, and the overflow height $\left(h_{b}\right)$, as an important design parameter, is the grate inlet height above the ground surface of the RBS (Figure 1). When the rainfall starts, runoff generated from the road flows into the RBS through curb inlets and infiltrates into the soil first. Then, after the soil is saturated, surface ponding occurs inside the RBS. When the ponding depth is greater than the overflow height, the runoff begins to flow into the grate inlet and then to the underground stormwater sewage system. When the infiltrated runoff reaches the storage layer of the RBS it can drain through the perforated pipe.

Most previous studies indicate that bioretention BMPs have a good hydrologic performance and pollutant removal efficiency in treating urban road runoff based on experimental and monitored data [24]. There was limited guidance and study on RBS design in China [25,26]. In the study conducted by Manganka et al. [27], the influence of rainfall characteristics, and inflow and outflow discharge on bioretention pollutant treatment performance was explored using conceptual model simulation data. Manganka et al. [24] found that the antecedent dry period is the most important factor affecting bioretention pollutant treatment efficiency while the study did not link the bioretention performance to actual design parameters directly. To evaluate and design RBS, the influence of design parameters, including the catchment area, longitudinal slope, road/street cross slope, curb inlet length, bioretention overflow height, and infiltration capacity, on RBS performance still needs to be explored.

Much more attention and focus should be paid to studying the curb inlet interception efficiency and its design because the curb inlet is an important hydraulic infrastructure for RBS. The curb inlet allows surface runoff on the road to get into bioretention cells and influences the road-bioretention strip's performance directly [25]. Some previous studies have explored the curb inlet interception efficiency evaluation [28], efficiency limitation [29], and influence factors [30] in urban drainage while not much research was found on curb inlets in RBS. An evidence-based curb inlet design guide for RBS is of great importance and urgency because current practices do not address RBS' hydraulic 
performance needs [26]. It is important to design a continuous RBS with a high curb-inlet interception efficiency and grate-inlet capacity to reduce the runoff on roads, ensure traffic safety, and relieve local flood inundation.

To understand the influence of design parameters for RBS, a performance evaluation of RBS is particularly important [31]. The main purpose of the study is to understand how the runoff generated from the upstream road is intercepted by the curb inlet and the grate inlet on the road and how the flow interception further influences the hydrological performance of the RBS system. In this study, the submodules for determining infiltration by zones (pervious and impervious zones in the simulation domain, Figure 2) and grate-inlet drainage from the 2D surface to the 1D pipe were added to the open source FullSWOF_2D (version 1.07, Lab. J. A. Dieudonné \& EPU Nice Sophia, Nice, France) [32] program to explore the continuous RBS performance and design concerns; the updated program was called FullSWOF-ZG. FullSWOF_2D means full shallow-water equations (SWEs) for overland flow in two-dimensional (2D) analysis which is programmed using $\mathrm{C}++$ to fully describe the rainfall-runoff and flow distribution progress on the surface in two-dimensional domains [33]. Therefore, the FullSWOF-ZG program can simulate impervious and pervious surfaces (different infiltration parameters/capabilities in different zones) in the RBS domain simultaneously under rainfall events. The 2D-1D grate-inlet drainage submodule enables the program to simulate the $2 \mathrm{D}$ overland runoff flowing into a grate inlet then to a $1 \mathrm{D}$ underground drainage pipe using the weir equation [34].

\section{Materials and Methods}

\subsection{Road-Bioretention Strip (RBS) Design}

The continuous RBS is mainly designed to remove runoff from the road, reduce local flood inundation, and improve runoff quality through bioretention. Curb inlet interception efficiency, bioretention ponding volume, bioretention infiltration capacity, and road grate inlet capacity should be taken into consideration when designing a continuous RBS.

\subsubsection{Curb Inlet Interception Efficiency Calculation}

There are three types of curb inlets commonly used in the USA. The undepressed curb inlet, which has one cross slope for the road and gutter so that the curb inlet has the same elevation as the nearby road surface (Figure 2), is also widely used in China [26]. The continuously depressed curb inlet is placed in gutters of streets with a composite cross slope [35]. The locally depressed curb inlet has an adjacent depression in the gutter near the inlet for effective flow interception, such as type $C$ (Figure 3) and type D curb inlets designed and constructed by the Texas Department of Transportation [36].

Current curb inlet designs in the USA are based on Hydraulic Engineering Circular No. 22 (HEC-22) from the Federal Highway Administration [37] and the Urban Street Stormwater Guide from the National Association of City Transportation Officials [25]. Design procedures of commonly-used inlet types are presented in HEC-22 and other specific design guidance is provided in different studies $[28,36]$. The interception efficiency $\left(E_{c i}\right)$ of undepressed curb inlets is calculated using the following Equations (1)-(3) adopted from HEC-22:

$$
\begin{gathered}
Q=(0.376 / n) S_{x}^{1.67} S_{0}^{0.5} T^{2.67} \\
L_{T}=0.817 Q^{0.42} S_{0}^{0.3}\left[1 /\left(n S_{x}\right)\right]^{0.6} \\
E_{c i}=1-\left[1-\left(L_{c i} / L_{T}\right)\right]^{1.8}
\end{gathered}
$$

where $L_{T}(\mathrm{~m})$ is the theoretical curb-inlet length required to intercept $100 \%$ of the flow; $E_{c i}(\%)$ is the inlet interception efficiency; $L_{c i}(\mathrm{~m})$ is the curb inlet length; $S_{x}$ and $S_{0}$ are the cross slope and longitudinal slope of the road/street, $Q$ is the flow rate on the road/street surface; $T$ is the spread width of the flow on the road/street surface; and $n(-)$ is Manning's roughness of the road surface. 


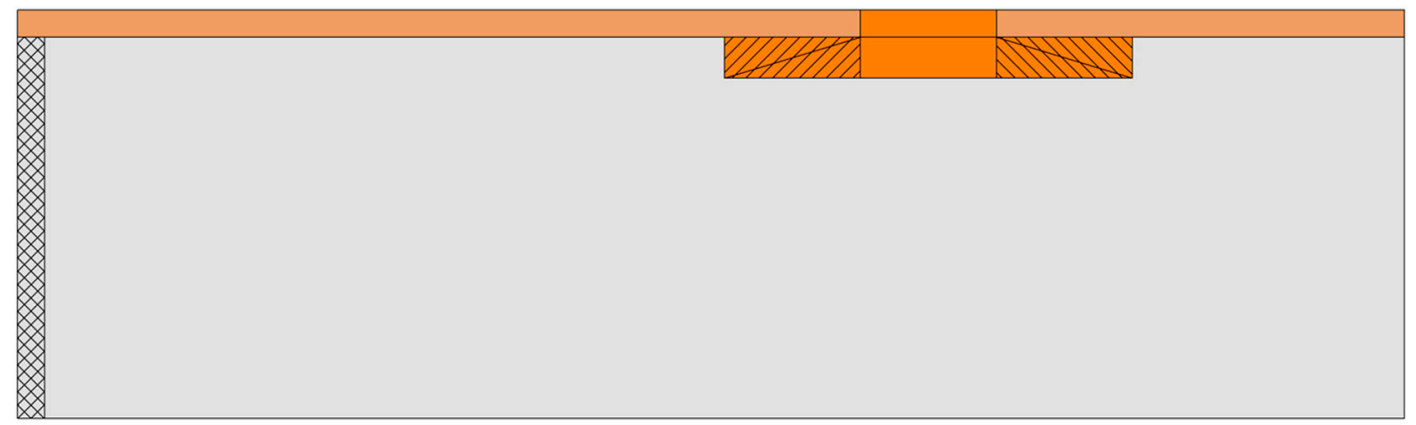

(a)

Legend

$\square$ Curb $\square$ Road surface
$\square$ Curb inlet $\square \square \Delta$ Upstream transition $\$ 11$ Downstream transition

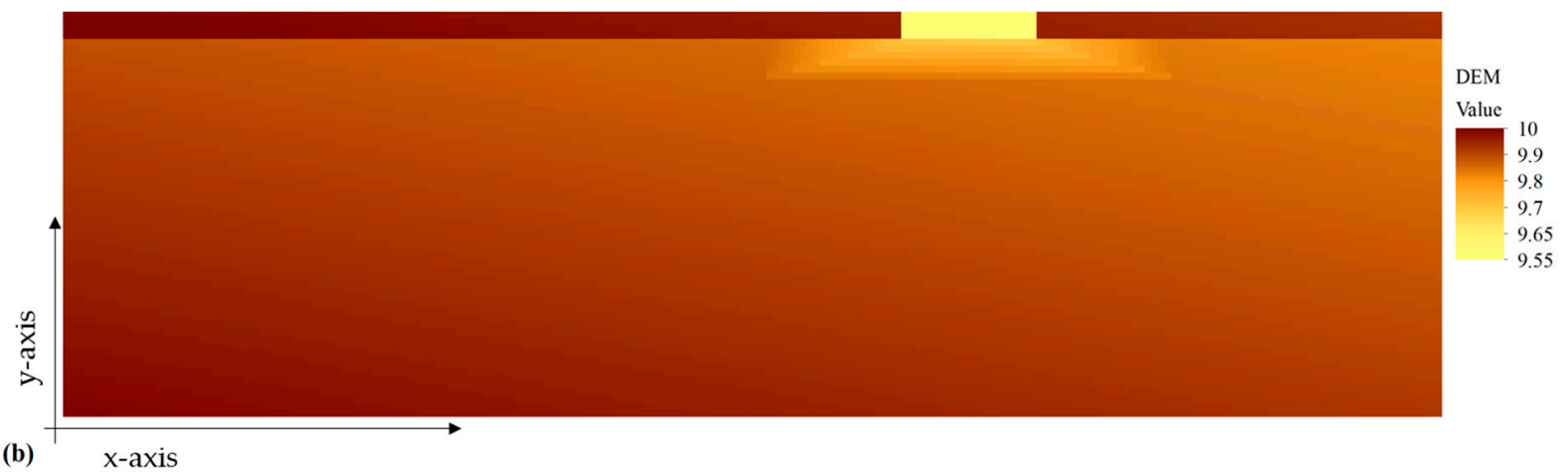

Figure 3. (a) Layout of type C curb inlet evaluation experiment (top view), and (b) DEM of case C01 with a longitudinal slope, $S_{0}=0.004$, and cross slope, $S_{x}=0.0208$.

\subsubsection{Bioretention Ponding Volume and Infiltration Capacity}

Overflow height/ponding depth provides a temporary storage space for stormwater runoff before it filters downward through the bioretention facility. The temporary ponding depth for bioretention facilities ranges from $5 \mathrm{~cm}$ (for mitigating sidewalk runoff alone, or in fast-draining soils) to up to $30 \mathrm{~cm}$ (for mitigating roadway runoff, or in slower-draining soils) [25]. The Delaware Green Technologies Design Manual and Model provides design guidance for bioretention systems, and allows a maximum ponding depth of $45 \mathrm{~cm}$ [38]. Allen et al. [14] declared the overall principles of the bioretention ponding volume and infiltration capacity design in their study. The ponding volume is designed by the corresponding catchment area and the design's rainfall depth.

The initial bioretention design specifications suggested the use of natural soils with high permeability [11]. Three soil textural classifications were specified, which include: Loamy sand, sandy loam, and loam. The Green-Ampt model was adopted to simulate the bioretention infiltration process in this study. The infiltration parameters included the saturated hydraulic conductivity $(K)$, moisture deficit $(\Delta \theta)$, and suction head $(\varphi)$. RBS with three different soils were studied here: Loamy sand $(K=51 \mathrm{~mm} / \mathrm{h}, \Delta \theta=0.410, \varphi=0.09 \mathrm{~m})$, sandy loam $(K=25 \mathrm{~mm} / \mathrm{h}, \Delta \theta=0.435, \varphi=0.218 \mathrm{~m})$, and loam $(K=13 \mathrm{~mm} / \mathrm{h}, \Delta \theta=0.451, \varphi=0.478 \mathrm{~m})$; and their infiltration parameter values were adopted based on the soil type [14]. The thickness of the soil layer was $0.45 \mathrm{~m}$ according to the bioretention design cases [39].

\subsection{FullSWOF-ZG Program and Model Test}

In this study, the open-source FullSWOF_2D program was revised and improved, and the updated program is called FullSWOF-ZG. The simplified SWEs model, as a Saint-Venant system [40], is widely used to simulate the incompressible Navier-Stokes flow occurring in rivers, channels, oceans, and land surfaces [41]. The 2D SWEs for the FullSWOF_2D program, including the continuity equation and 
two momentum equations in the $x$ and $y$ directions, are stated as the following equations for each computational cell (center coordinates $x$ and $y$ ):

$$
\begin{gathered}
\frac{\partial h}{\partial t}+\frac{\partial h u}{\partial x}+\frac{\partial h v}{\partial y}=R_{i}(x, y)-f(x, y) \\
\frac{\partial h u}{\partial t}+\frac{\partial}{\partial x}\left(h u^{2}+\frac{g h^{2}}{2}\right)+\frac{\partial}{\partial y}(h u v)=-g h\left(\frac{\partial z}{\partial x}+S_{f x}\right) \\
\frac{\partial h v}{\partial t}+\frac{\partial}{\partial x}(h u v)+\frac{\partial}{\partial y}\left(h v^{2}+\frac{g h^{2}}{2}\right)=-g h\left(\frac{\partial z}{\partial y}+S_{f y}\right)
\end{gathered}
$$

where $R_{i}(x, y)(\mathrm{m} / \mathrm{s})$ is the cell's rainfall intensity; $f(x, y)(\mathrm{m} / \mathrm{s})$ is the cell's infiltration rate; $h(\mathrm{~m})$ is the cell's water depth; $z(\mathrm{~m})$ is the cell topography elevation as a function of the cell location or $x$ and $y$ coordinates; $u(\mathrm{~m} / \mathrm{s})$ and $v(\mathrm{~m} / \mathrm{s})$ are the cell's depth-averaged velocities in the $x$ and $y$ directions, respectively; $S_{f x}$ and $S_{f y}$ are the cell's friction slopes in the $x$ and $y$ directions, respectively; $g\left(\mathrm{~m} / \mathrm{s}^{2}\right)$ is the gravity acceleration; and $t(\mathrm{~s})$ is time.

The FullSWOF_2D program fully solves SWEs on a structured mesh (square cells) in two dimensions using the finite volume method that ensures mass conservation compared to the finite difference method [42]. A well-balanced numerical scheme was adopted to guarantee the positivity of water depth and the preservation of steady states for specific hydrological features such as during wet-dry transitions and tiny water depths [32,43]. Different boundary conditions, friction laws, and numerical schemes were developed that make the program a very powerful overland flow simulation software. A modified bi-layer (crust- and soil-layer) Green-Ampt infiltration model [44] to calculate $f(x, y)$ for Equation (4) was coded in the FullSWOF_2D [42], which enables the program to simulate the overland flow on impervious and pervious surfaces simultaneously.

The updated FullSWOF-ZG program includes the rainfall input and the infiltration determination by zone and a new 2D-1D drainage inlet submodule. Therefore, the program can simulate impervious road (Figures 3 and 4) and pervious bioretention surfaces (Figure 4) with different infiltration capabilities simultaneously. The simulation domain can have several grate inlets (Figure 4); therefore, the $2 \mathrm{D}$ overland flow can drain into these $2 \mathrm{D}$ grate inlets (rectangles) to become a $1 \mathrm{D}$ flow in underground drainage pipes. Currently, the FullSWOF-ZG program does not further simulate the $1 \mathrm{D}$ flow in the drainage pipes, assuming the pipe capability is large enough to accept all inflow from inlets [37]. The simulation domain has curb inlets connecting the road (impervious surface) and the RBS (Figures 2 and 4). Normally, the runoff on the road flows through the curb inlet(s) into the RBS. Only under extreme conditions would the runoff in the RBS be able to flow back to the road, but the extreme conditions were not simulated in this study.

The grate-inlet flow-intercepting capacity $\left(Q_{g r}, \mathrm{~m}^{3} / \mathrm{s}\right)$ from the $2 \mathrm{D}$ overland flow to the $1 \mathrm{D}$ drainage pipe flow is calculated using the weir Equation (7) [34] applied to the $k$ cells within the grate inlet:

$$
Q_{g r}=\sum_{i=1}^{k} k_{w} \sqrt{2 g} L_{w} h_{2 D(i)}^{3 / 2}
$$

where $k_{w}(-)$ is the discharge coefficient of the weir flow $=0.368$ [45]; $g\left(\mathrm{~m} / \mathrm{s}^{2}\right)$ is the gravity acceleration; $L_{w}(\mathrm{~m})$ is the flow length (=cell size); $h_{2 D(i)}(\mathrm{m})$ is the overland-flow water depth for the $i$ th cell; and $k$ is the total number of the cells within the grate inlet. Each grate inlet in the simulation domain is considered to have an elevation difference (e.g., $5 \mathrm{~cm}$ lower) from the surrounding road cells.

The FullSWOF_2D program was previously tested and verified for overland flow on pervious surfaces [46]. In this study, FullSWOF-ZG was tested separately using two kinds of modeling cases: eight pervious surfaces under indoor simulated rainfall events and twenty curb inlets with local depression and inflow from upstream. The inlet geometry was represented by the detailed high-resolution digital elevation model (DEM). These testing cases are described below in detail separately. 


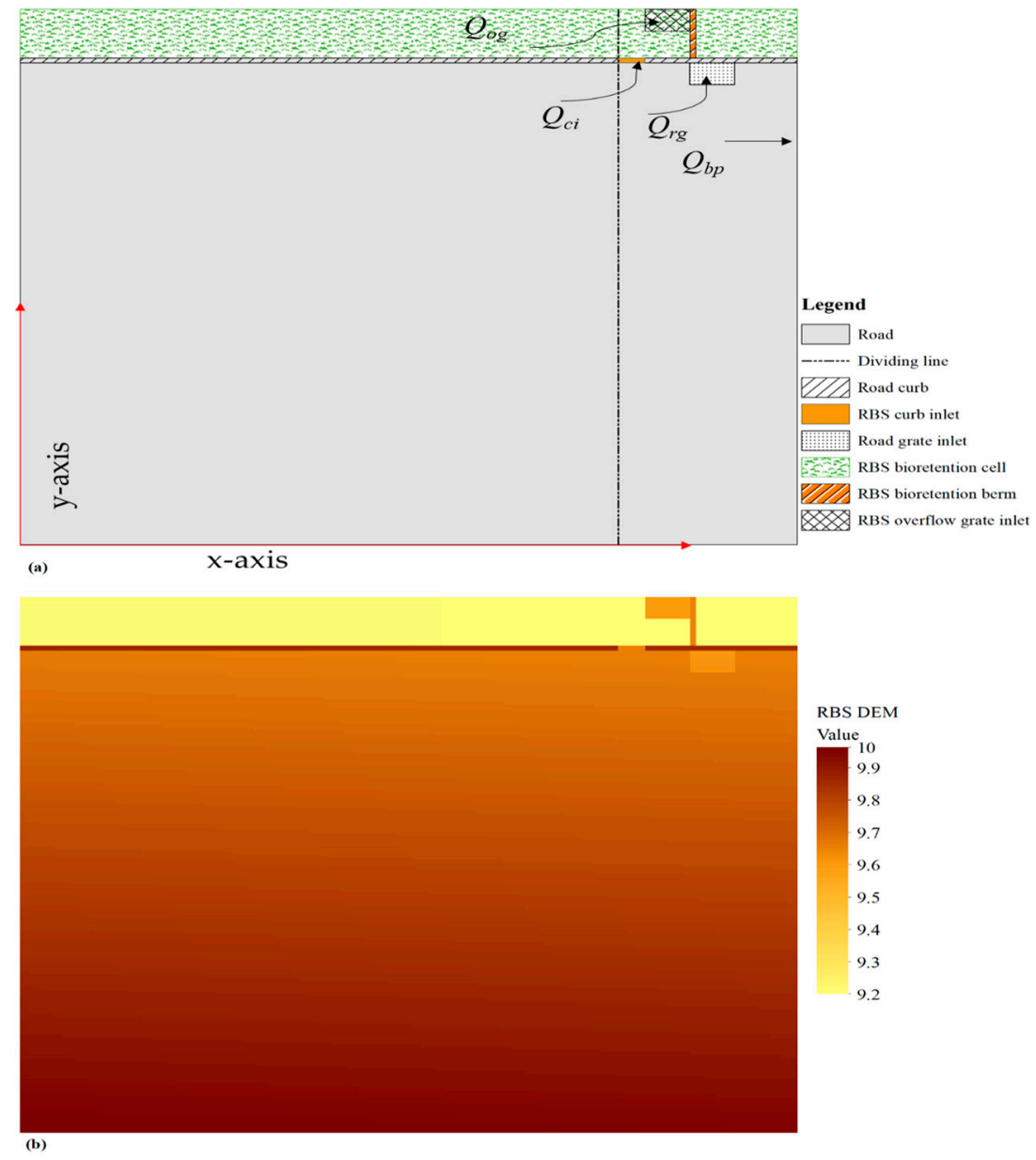

Figure 4. (a) Plan view and (b) DEM for RBS04 (Table 1) with a longitudinal slope, $S_{0}=0.001$, and cross slope, $S_{x}=0.030$.

\subsubsection{Pervious Surface Modeling Cases}

FullSWOF-ZG was validated using eight pervious surfaces under indoor simulated rainfall events as testing cases to demonstrate that it can be used to accurately simulate overland flow on pervious surfaces. The experiment was conducted at Texas A\&M University to investigate the travel time and runoff characteristics of overland flow on pervious clay surfaces. The data from indoor tests consist of the discharge rate and surface runoff depth under a varying rainfall intensity and slope of the surface.

The tests were conducted on a steel-framed bed $1.83 \mathrm{~m}(6 \mathrm{ft})$ wide, $9.14 \mathrm{~m}(30 \mathrm{ft})$ long, and $0.36 \mathrm{~m}$ (14 in) deep. The test bed was filled with clay and compacted with a lawn roller and left outdoors for over a month for natural compaction. The experiments were conducted using a rainfall simulator with a maximum capacity of up to $114.3 \mathrm{~mm} / \mathrm{h}(4.5 \mathrm{in} / \mathrm{h})$. Two samplers equipped with bubbler flow modules were used to collect discharge depths and surface runoff depths near the outlet with $2.54 \times 10^{-6} \mathrm{~m}(0.0001 \mathrm{in})$ resolution every minute. The discharge depth was measured with a $22.5^{\circ} \mathrm{V}$-notch weir box. The rainfall intensity was monitored using an inline flowmeter connected to the rainfall simulator. The tipping bucket rain gauge was also used to double check the rainfall depth. The rainfall was stopped at $10 \mathrm{~min}$ after the peak discharge was attained and the discharge measurement was done until the runoff ceased. The slope of the test bed was $0.02 \%, 0.1 \%, 0.2 \%, 0.5 \%$, and $1.04 \%$. Different slopes for the overland flow were achieved by raising or lowering the steel-framed bed. Six rainfall events were tested for each slope, with a total of 30 events for the experiment.

Eight of the 30 rainfall events were chosen as the test cases in this study. Four test cases had a slope of $0.1 \%$, three cases of $0.2 \%$, and one case of $0.5 \%$. The cell size in the $x$ - and $y$-directions of the simulation domain was $0.15 \mathrm{~m}(0.5 \mathrm{ft})$. The Manning's friction formula with $n=0.02$ was 
selected among three friction formulas of FullSWOF-ZG. The Green-Ampt model was used to simulate the infiltration process of the experiment. The saturated hydraulic conductivity $(K=1.524 \mathrm{~mm} / \mathrm{h})$, moisture deficit $(\Delta \theta=0.15)$, and suction head $(\varphi=0.208 \mathrm{~m})$ parameters' values were adopted in the simulation based on the field survey.

The goodness of fit for the simulated hydrograph was evaluated using the Nash-Sutcliffe efficiency (NSE) coefficient [47]:

$$
N S E=1-\frac{\sum_{i=1}^{m}\left(Q_{o i}-Q_{s i}\right)^{2}}{\sum_{i=1}^{m}\left(Q_{o i}-\bar{Q}\right)^{2}}
$$

where $Q_{o i}\left(\mathrm{~m}^{3} / \mathrm{s}\right)$ is the $i$ th observed runoff rate, $Q_{s i}\left(\mathrm{~m}^{3} / \mathrm{s}\right)$ is the corresponding simulated runoff rate, $\bar{Q}\left(\mathrm{~m}^{3} / \mathrm{s}\right)$ is the mean observed runoff rate, and $m(-)$ is the total number of observed runoff rates. The NSE values for eight rainfall events were calculated to evaluate the FullSWOF-ZG performance.

\subsubsection{Curb Inlet Modeling Cases}

Hammonds and Holley [36] performed a series of laboratory experiments of Texas type $C$ and type D locally depressed curb inlets to quantify the interception efficiencies of these inlets under different longitudinal slopes, cross slopes, and upstream inflows. Only the type C curb inlet geometry (Figure 3) and monitored data were used in this study to evaluate the FullSWOF-ZG model.

According to the dimensions of the experimental facility, the length and width of the simulation

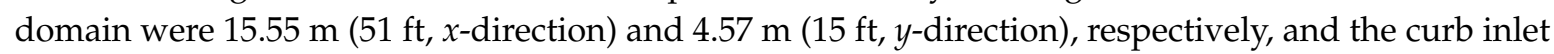
was $4.57 \mathrm{~m}(15 \mathrm{ft})$ long in total. The type $\mathrm{C}$ inlet included a $1.52 \mathrm{~m}(5 \mathrm{ft})$ opening and $1.52 \mathrm{~m}(5 \mathrm{ft})$ upstream and downstream transition sections that change elevation or depression gradually from the undepressed section into the fully depressed inlet section over the $1.52 \mathrm{~m}(5 \mathrm{ft})$ length. The total width of the curb inlet depression was $0.457 \mathrm{~m}(1.5 \mathrm{ft})$ with a depressed depth of $0.010 \mathrm{~m}(0.33 \mathrm{ft})$ and a depression width of $0.368 \mathrm{~m}(1.2 \mathrm{ft})$ for the type $C$ inlet [30,48]. The simulation domain was represented by a detailed and high-resolution DEM (Figure $3 \mathrm{~b}$ ) with a cell size equal to $0.076 \mathrm{~m}$ $(0.25 \mathrm{ft})$. The elevation of every computation cell was calculated by considering the longitudinal slope, cross slope, local depressed slope of the curb inlet, and slopes of the inlet's upstream and downstream transition parts.

The Manning's law among the three friction choices (Manning's law, Darcy-Weisbach law, and Laminar law) in FullSWOF-ZG was used in the simulation, and the roughness coefficient determined for the laboratory roadway was 0.018 , as reported by Hammonds and Holley [36]. The longitudinal ( $x$-direction) and cross ( $y$-direction) slopes for the simulation domain were from left to right and bottom to top, respectively (Figure 3).

The imposed discharge condition among five available boundary condition choices (imposed water height, wall condition, Neumann condition, periodic condition, and imposed discharge) in FullSWOF-ZG was chosen as the left or upstream boundary condition of the domain. The imposed discharge for the boundary cells within the spread $(T)$ was approximately assumed as the total inflow rate $\left(Q_{i}\right)$ divided by the number of the cells within the spread and was equal to 0 for other boundary cells outside of the spread. The top and right (downstream) boundary of the simulation domain were set as a Neumann condition that allows the flow to get out of the simulation domain. At the top of the simulation domain, those cells outside the curb inlet had higher elevations to prevent the outflow. The bottom boundary of the simulation domain (Figure $3 b$ ) had the highest elevation along the $y$-direction and was set as a wall boundary condition to guarantee that the flow would not pass through the bottom boundary.

\subsection{Road-Bioretention Modeling Cases}

Figure 4, as an example, shows the plan view and high-resolution DEM for the modeling case RBS04 (Table 1) with an undepressed curb inlet. Figure 4a includes the different parts of the RBS system: The road with longitudinal and cross slopes, the RBS, a curb inlet, a grate inlet on the road, 
an overflow grate inlet and a berm at the end of the RBS, and the curb separating the road and RBS. The RBS performance of ponding and infiltrating the runoff is affected by the longitudinal slope $\left(S_{0}\right)$, cross slope $\left(S_{x}\right)$, curb inlet interception efficiency $\left(E_{c i}\right)$, bioretention depth $\left(D_{b}\right)$, overflow height $\left(h_{b}\right)$, and the RBS's soil infiltration parameters, such as the saturated hydraulic conductivity $(K)$, suction head $(\varphi)$, and moisture deficit $(\Delta \theta)$. Different modeling cases were established to explore the influence of these design parameters on the RBS performance. Even when the RBS was flat in the $y$-direction with a lower elevation (i.e., bioretention depth, $D_{b}$ ) than the road surface, the RBS had the same length and longitudinal slope, $S_{0}$, in the $x$-direction as the road did (Figure 4).

Table 1. Parameter values of 20 modeling cases of the road-bioretention strip (RBS) systems with an undepressed curb inlet and grate inlets (Figure $4 \mathrm{a}$ ).

\begin{tabular}{|c|c|c|c|c|c|c|c|c|c|}
\hline Case No. & $\begin{array}{c}L \\
(\mathrm{~m})\end{array}$ & $\begin{array}{l}S_{0} \\
(-)\end{array}$ & $\begin{array}{l}S_{x} \\
(-)\end{array}$ & $\begin{array}{l}L_{c i} \\
(\mathrm{~m})\end{array}$ & $\begin{array}{l}D_{b} \\
(\mathrm{~m})\end{array}$ & $\begin{array}{c}K \\
(\mathrm{~mm} / \mathrm{h})\end{array}$ & $\begin{array}{c}\varphi \\
(\mathrm{m})\end{array}$ & $\begin{array}{l}\Delta \theta \\
(-)\end{array}$ & $\begin{array}{c}V_{p c} \\
\left(\mathrm{~m}^{3}\right)\end{array}$ \\
\hline RBS01 & 40 & 0.001 & 0.010 & 1.20 & 0.25 & 51 & 0.090 & 0.410 & 7.44 \\
\hline RBS02 & 30 & 0.001 & 0.015 & 0.90 & 0.30 & 25 & 0.218 & 0.435 & 7.33 \\
\hline RBS03 & 20 & 0.001 & 0.020 & 0.60 & 0.35 & 13 & 0.478 & 0.451 & 6.08 \\
\hline RBS04 & 10 & 0.001 & 0.030 & 0.45 & 0.45 & 51 & 0.090 & 0.410 & 4.28 \\
\hline RBS05 & 40 & 0.003 & 0.015 & 1.20 & 0.25 & 51 & 0.090 & 0.410 & 5.68 \\
\hline RBS06 & 30 & 0.003 & 0.020 & 0.90 & 0.30 & 25 & 0.218 & 0.435 & 6.33 \\
\hline RBS07 & 20 & 0.003 & 0.030 & 0.60 & 0.35 & 13 & 0.478 & 0.451 & 5.62 \\
\hline RBS08 & 10 & 0.003 & 0.040 & 0.45 & 0.45 & 51 & 0.090 & 0.410 & 4.16 \\
\hline RBS09 $^{1}$ & 40 & 0.005 & 0.020 & 1.20 & 0.25 & 51 & 0.090 & 0.410 & 3.93 \\
\hline RBS10 & 30 & 0.005 & 0.030 & 0.90 & 0.30 & 25 & 0.218 & 0.435 & 5.32 \\
\hline RBS11 & 20 & 0.005 & 0.040 & 0.60 & 0.35 & 13 & 0.478 & 0.451 & 5.16 \\
\hline RBS12 & 10 & 0.005 & 0.045 & 0.45 & 0.45 & 51 & 0.090 & 0.410 & 4.03 \\
\hline $\mathrm{RBS}^{1}{ }^{1}$ & 40 & 0.007 & 0.030 & 1.20 & 0.25 & 51 & 0.090 & 0.410 & 2.79 \\
\hline RBS14 & 30 & 0.007 & 0.040 & 0.90 & 0.30 & 25 & 0.218 & 0.435 & 4.32 \\
\hline RBS15 & 20 & 0.007 & 0.045 & 0.60 & 0.35 & 13 & 0.478 & 0.451 & 4.71 \\
\hline RBS16 & 10 & 0.007 & 0.055 & 0.45 & 0.45 & 51 & 0.090 & 0.410 & 3.91 \\
\hline RBS17 $^{1}$ & 40 & 0.010 & 0.040 & 1.20 & 0.25 & 51 & 0.090 & 0.410 & 1.93 \\
\hline $\mathrm{RBS}^{1}{ }^{1}$ & 30 & 0.010 & 0.045 & 0.90 & 0.30 & 25 & 0.218 & 0.435 & 3.04 \\
\hline RBS19 & 20 & 0.010 & 0.055 & 0.60 & 0.35 & 13 & 0.478 & 0.451 & 4.02 \\
\hline RBS20 & 10 & 0.010 & 0.065 & 0.45 & 0.45 & 51 & 0.090 & 0.410 & 3.72 \\
\hline
\end{tabular}

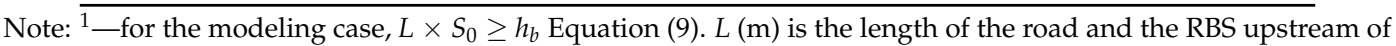
the curb inlet (Figure 4), $L_{c i}(\mathrm{~m})$ is the opening length of the curb inlet, $h_{b}(\mathrm{~m})$ is the overflow height of the grate inlet inside the RBS, and the bioretention depth, $D_{b}=h_{b}+0.05 \mathrm{~m}, K(\mathrm{~mm} / \mathrm{h})$ is the saturated hydraulic conductivity, $\varphi(\mathrm{m})$ is the soil suction head, and $\Delta \theta$ is the soil moisture deficit, $V_{p c}\left(\mathrm{~m}^{3}\right)$ is the calculated bioretention ponding volume when overflow occurs.

There was a grate inlet at the end of the RBS where the grate inlet opening was $h_{b}$ above the RBS ground surface. The elevation difference between the grate inlet opening and the RBS ground surface is called the overflow height, $h_{b}$, ranging from $0.25 \mathrm{~m}$ (10 in) to $0.45 \mathrm{~m}$ (18 in) in this study (Table 1). In the USA, the initial concept of bioretention has a shallow ponding depth of $0.15 \mathrm{~m}$ (6 in), but recent green infrastructure design manuals allow for $0.30 \mathrm{~m}$ (12 in) to $0.45 \mathrm{~m}$ (18 in) of ponding depth [14]. Only when the water depths near the grate inlet are greater than $h_{b}$, will the runoff in RBS flow into the grate inlet then to the underground drainage pipe system. There is a berm at the end of the RBS (Figures 1 and 4) to pond the runoff inside the RBS, which facilitates infiltration downward and possible overflow into the grate inlet. The berm height was set as the same as the bioretention depth, $D_{b}$, to prevent the longitudinal outflow from the RBS since $D_{b}>h_{b}$.

The simulation domain is divided into two zones by an imaginary dividing line (Figure 4a): The upstream or left of the line has uniform rainfall and the downstream or right of the line has no rainfall. A part of the runoff generated on the road surface is intercepted by the curb inlet $\left(Q_{c i}\right.$ in Figure 4), then, a part of the bypass runoff from the inlet is captured by the grate inlet on the road $\left(Q_{r g}\right)$ and leaves the simulated road surface through the grate inlet. Finally, the remainder of the runoff is 
discharged downstream along the road $\left(Q_{b p}\right)$. The runoff into the bioretention infiltrates downward or overflows through the bioretention grate inlet $\left(Q_{o g}\right)$ when the ponding depth is greater than $h_{b}$.

The bioretention ponding volume $\left(V_{p c}\right)$ was calculated for each modeling case in this study when the overflow occurred, and did not consider the vegetation volume fraction of the bioretention facility. The impact of the longitudinal slope was included when calculating $V_{p c}$ using the following Equation (9). The $V_{p c}$ is calculated with two situations: (1) The ponding length is larger than the upstream catchment length, $L\left(L \times S_{0}<h_{b}\right)$; and (2) the ponding length is equal to or smaller than the upstream catchment length $\left(L \times S_{0} \geq h_{b}\right)$ :

$$
V_{p c}=\left\{\begin{array}{c}
\left(L \times h_{b}-\frac{L^{2} \times S_{0}}{2}\right) \times w_{b}-h_{b} \times A_{g r} L \times S_{0}<h_{b} \\
\frac{h_{b}}{S_{0}} \times \frac{h_{b}}{2} \times w_{b}-h_{b} \times A_{g r} L \times S_{0} \geq h_{b}
\end{array}\right.
$$

where $V_{p c}\left(\mathrm{~m}^{3}\right)$ is the calculated ponding volume based on the RBS geometry; $w_{b}(\mathrm{~m})$ is the RBS width $(1 \mathrm{~m}) ; L(\mathrm{~m})$ is the RBS length, which is the same as the road length; $S_{0}$ is the RBS's longitudinal slope; $h_{b}(\mathrm{~m})$ is the RBS overflow height; and $A_{g r}\left(\mathrm{~m}^{2}\right)$ is the overflow grate inlet area.

Twenty cases of the RBS systems were modeled in this study by having four contributing-watershed lengths (10-40 m, 32.8-131.2 ft) and five longitudinal slopes (0.001-0.01) (Table 1). When the road length and longitudinal slope were increased, the cross slope and the curb-inlet length, $L_{c i}$, were increased also as real design situations for the curb inlet to intercept a similar amount of the runoff. When the contributing watershed was enlarged by increasing $L$, a longer $L_{c i}$ allowed more runoff to flow into the RBS. Other corresponding RBS's parameter values were changed correspondingly as shown/summarized in Table 1. The RBS system has eight key modeling parameters, and to fully understand the RBS system performance and the influence from each parameter, a large number of modeling cases is required, which was not studied here. For all 20 cases (Table 1), the roadway width was $10 \mathrm{~m}$ (y-direction, Figure 4) for a two-lane road, including necessary space for shoulders and gutters [49]. The curb width, which was the same as the curb-inlet width, was $0.1 \mathrm{~m} \mathrm{(4} \mathrm{in)} \mathrm{to} \mathrm{separate} \mathrm{the} \mathrm{road} \mathrm{and} \mathrm{the} \mathrm{RBS.} \mathrm{The} \mathrm{RBS} \mathrm{width} \mathrm{was} 1.0 \mathrm{~m}$ (40 in), and the maximum ponding depth or the bioretention depth, $D_{b}$, was set as $0.05 \mathrm{~m}$ above the grate-inlet overflow height, $h_{b}$, i.e., $D_{b}=h_{b}+0.05 \mathrm{~m}$ for all 20 modeling cases. The road grate inlet was a rectangle of $0.75 \mathrm{~m}$ ( $30 \mathrm{in}$, along with the $x$-direction) by $0.45 \mathrm{~m}$ (18 in) and was made to be $0.05 \mathrm{~m}$ ( 2 in) lower than the surrounding road-surface cells for the model simulation here. The grate inlet in the RBS was the same size for all modeling cases.

For the modeling case, RBS04 (Figure 4), the simulation domain length was $13 \mathrm{~m}$ ( $43 \mathrm{ft}, x$-direction), including $10 \mathrm{~m}(33 \mathrm{ft})$ of road surface before the inlet and a width of $10 \mathrm{~m}(33 \mathrm{ft})$, which was the curb-inlet runoff contributing watershed that received the rainfall (Figure 4). The computational cell/grid size for the simulation domain was $0.05 \mathrm{~m}(3 \mathrm{in})$ both in the $x$ - and $y$-directions with a total of 57,200 cells for the case, RBS04. There was a total of 135 cells in each grate inlet $[(0.75 / 0.05) \times(0.45 / 0.05)]$ or $k=135$ in Equation (7), and the curb inlet $\left(L_{c i}=0.45 \mathrm{~m}\right)$ was 18 cells $[(0.45 / 0.05) \times(0.1 / 0.05)]$ in the simulation domain of RBS04.

To compare the effect of different design parameters of the RBS systems, there were another 20 modeling cases (Rd01-Rd20) that had the same road surface without a curb inlet and RBS. Thus, all Rd modeling cases were the road only in the simulation domain. Each Rd modeling case was the same length $(L)$, and longitudinal and cross slopes $\left(S_{0}\right.$ and $\left.S_{x}\right)$ for the road surface as the corresponding RBS modeling case (Table 1).

All cell's elevations were calculated when the bottom left corner reference cell's elevation (the highest in the domain) was assumed to be $10 \mathrm{~m}$ as shown in Figure $4 \mathrm{~b}$. The road surface and bioretention ground elevations, therefore, vary with the longitudinal and cross slopes set for each modeling case (Table 1). All cells for the $0.1 \mathrm{~m}$ curb were set $0.2 \mathrm{~m}$ higher than the road surface cells. The cell's elevations inside the curb inlet cells were calculated using the same cross slope of the road surface, which helps and allows the runoff to flow into the RBS. The uniform rainfall intensity was 
$6.94 \times 10^{-5} \mathrm{~m} / \mathrm{s}(250 \mathrm{~mm} / \mathrm{h}, 10 \mathrm{in} / \mathrm{h})$ and lasted $1200 \mathrm{~s}(20 \mathrm{~min})$ to generate enough runoff reach the ponding volume, but the total simulation period was $2400 \mathrm{~s}$. A portion (virtual road-surface in Figure 4a) of the simulation domain just downstream of the curb inlet was simulated without rainfall because the focus of the study was to investigate the impact of the runoff generated upstream of the curb inlet.

\section{Results and Discussion}

\subsection{FullSWOF-ZG Testing Results}

In a previous study [46], FullSWOF_2D was updated and tested with published rainfall-runoff data on pervious surfaces adopted from Esteves's study [44]. It showed that the updated program provided consistent simulation results with observed data during the whole rainfall period. The details of the testing results for FullSWOF-ZG for pervious surfaces with data collected in Texas A\&M University and type $C$ curb inlet cases with data from the published report are introduced below.

\subsubsection{Results for Pervious Surfaces}

The comparison of observed and simulated discharge hydrographs of one pervious surface under four rainfall events is shown in Figure 5. The simulated hydrographs closely follow with the observed hydrographs for the sample results. The discharge NSE values ranged from 0.79 to 0.93 (Table 2, average \pm standard deviation as $0.86 \pm 0.05$ ) for three pervious surfaces (slopes) under eight rainfall events. Table 2 also presents the comparison results of the simulated and observed runoff volume and peak discharges. The percent differences of the simulated runoff volume and peak discharges were $2.8 \pm 13.3 \%$ (average \pm standard deviation) and $13.8 \pm 12.8 \%$, respectively. Figure 5 a is the case with the highest runoff-volume percent difference and Figure $5 \mathrm{c}$ is the case with the second highest peak-discharge percent difference. The indoor testing bed was $0.36 \mathrm{~m}$ deep, which was much larger than the cumulative infiltration depth during the experiment. The indoor testing bed was deep and provided enough soil space for the infiltrated runoff. The results for all eight rainfall events (Table 2 and Figure 5) show that the FullSWOF-ZG program predicted the rainfall-runoff process of overland flows on a pervious surface with reasonable accuracy.
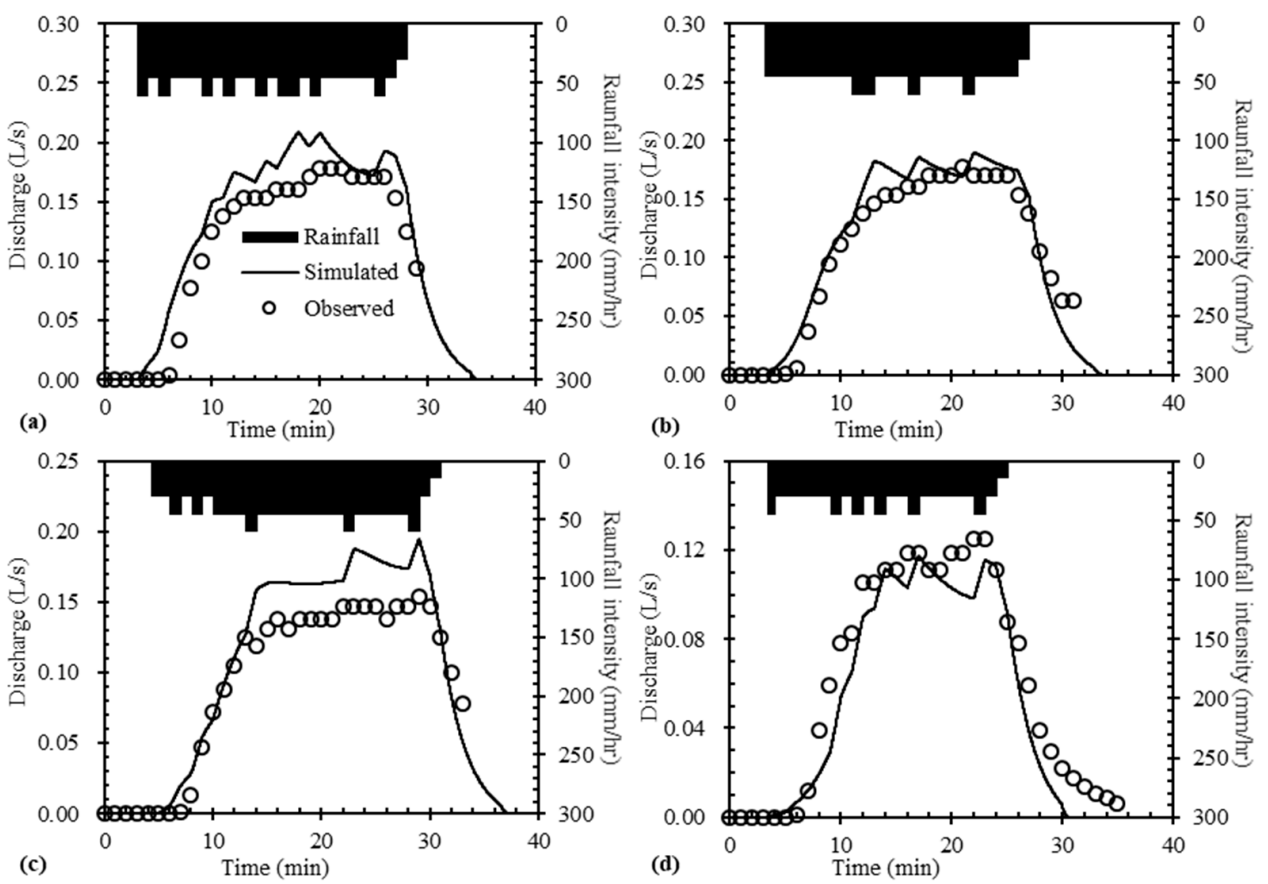

Figure 5. Simulated and observed hydrographs of one pervious surface under four events: (a) S01R1, (b) S01R2, (c) S01R3, and (d) S01R4 (Table 2). 
Table 2. Comparison of simulated and observed discharge and volume results for eight rainfall events.

\begin{tabular}{lccccccccc}
\hline Events & $\begin{array}{c}S_{\mathbf{0}} \\
\mathbf{( - )}\end{array}$ & $\begin{array}{c}N S E \\
\mathbf{( - )}\end{array}$ & $\begin{array}{c}V_{r} \\
\left(\mathbf{m}^{3}\right)\end{array}$ & $\begin{array}{c}V_{o b} \\
\left(\mathbf{m}^{\mathbf{3}}\right)\end{array}$ & $\begin{array}{c}V_{s i} \\
\left(\mathbf{m}^{\mathbf{3}}\right)\end{array}$ & $\begin{array}{c}\Delta V_{\boldsymbol{p}} \\
\mathbf{( \% )}\end{array}$ & $\begin{array}{c}\mathbf{Q}_{p o} \\
(\mathbf{L} / \mathbf{s})\end{array}$ & $\begin{array}{c}Q_{p s} \\
(\mathbf{L} / \mathbf{s})\end{array}$ & $\begin{array}{c}\Delta Q_{p} \\
(\mathbf{\%})\end{array}$ \\
\hline S01R1 & 0.001 & 0.85 & 0.35 & 0.20 & 0.25 & 22.2 & 0.18 & 0.21 & 15.4 \\
S01R2 & 0.001 & 0.93 & 0.32 & 0.20 & 0.21 & 4.9 & 0.18 & 0.19 & 5.4 \\
S01R3 & 0.001 & 0.83 & 0.32 & 0.19 & 0.22 & 14.6 & 0.15 & 0.19 & 23.5 \\
S01R4 & 0.001 & 0.92 & 0.20 & 0.13 & 0.11 & -16.7 & 0.12 & 0.12 & 0.0 \\
S02R5 & 0.002 & 0.83 & 0.21 & 0.12 & 0.12 & 0.0 & 0.12 & 0.15 & 22.2 \\
S02R6 & 0.002 & 0.84 & 0.27 & 0.15 & 0.15 & 0.0 & 0.12 & 0.15 & 22.2 \\
S02R7 & 0.002 & 0.79 & 0.25 & 0.16 & 0.14 & -13.3 & 0.15 & 0.14 & -6.9 \\
S05R8 & 0.005 & 0.87 & 0.19 & 0.09 & 0.10 & 10.5 & 0.12 & 0.16 & 28.6 \\
\hline
\end{tabular}

Note: $S_{0}(-)$ is the testing bed's surface slope, $V_{r}\left(\mathrm{~m}^{3}\right)$ is the calculated rainfall volume, $V_{o b}\left(\mathrm{~m}^{3}\right)$ is the observed total runoff volume, $V_{s i}\left(\mathrm{~m}^{3}\right)$ is the simulated total runoff volume, $\Delta V_{p}(\%)$ is the percent difference of the simulated runoff volume $=\left(V_{s i}-V_{o b}\right) /\left[\left(V_{o b}+V_{s i}\right) / 2\right] \times 100 \%, Q_{p o}(\mathrm{~L} / \mathrm{s})$ is the observed peak runoff rate, $Q_{p s}(\mathrm{~L} / \mathrm{s})$ is the simulated peak runoff rate, $\Delta Q_{p}(\%)$ is the percent difference of the simulated peak discharge $=\left(Q_{p s}-Q_{p o}\right) /\left[\left(Q_{p o}+\right.\right.$ $\left.\left.Q_{p s}\right) / 2\right] \times 100 \%$.

\subsubsection{Results of Curb Inlet Interception}

Twenty modeling cases for the type $\mathrm{C}$ inlet on the road surfaces (Table 3) covered six longitudinal slopes (0.004-0.07), two cross slopes (0.0208 and 0.0407), and 12 spreads (2.16-4.27 m), and 20 upstream inflows $\left(Q_{\text {in }} 0.1031-0.2453 \mathrm{~m}^{3} / \mathrm{s}\right)$. All these model input parameter values were exactly the same as the experimental setup information $[36,48]$. The curb inlet interception efficiency $\left(E_{c i}\right)$ was evaluated with the curb intercepted flow rate (observed $Q_{\text {cio }}$ or simulated $Q_{c i s}$ ) divided by the upstream inflow rate $\left(Q_{\text {in }}\right)$ after the system reached equilibrium.

Table 3. Curb inlet test cases' setting parameters and simulation results.

\begin{tabular}{|c|c|c|c|c|c|c|c|c|c|c|}
\hline Case No. & $\begin{array}{l}S_{0} \\
(-)\end{array}$ & $\begin{array}{l}S_{x} \\
(-)\end{array}$ & $\begin{array}{c}T \\
(\mathrm{~m})\end{array}$ & $\begin{array}{c}Q_{i n} \\
\left(\mathrm{~m}^{3} / \mathrm{s}\right)\end{array}$ & $\begin{array}{c}Q_{c i o} \\
\left(\mathrm{~m}^{3} / \mathrm{s}\right)\end{array}$ & $\begin{array}{l}E_{c i o} \\
(\%)\end{array}$ & $\begin{array}{c}Q_{c i s} \\
\left(\mathrm{~m}^{3} / \mathrm{s}\right)\end{array}$ & $\begin{array}{l}E_{c i s} \\
(\%)\end{array}$ & $\begin{array}{l}\Delta E \\
(\%)\end{array}$ & $\begin{array}{l}P D_{E} \\
(\%)\end{array}$ \\
\hline $\mathrm{C} 01$ & 0.004 & $0.0208(1: 48)$ & 4.27 & 0.2400 & 0.1256 & 52.3 & 0.1306 & 54.4 & 2.1 & 3.9 \\
\hline $\mathrm{C} 02$ & 0.004 & 0.0208 & 4.27 & 0.1076 & 0.0829 & 77.0 & 0.0872 & 81.0 & 4.0 & 5.0 \\
\hline $\mathrm{C} 03$ & 0.010 & 0.0208 & 4.27 & 0.2361 & 0.1098 & 46.5 & 0.1185 & 50.2 & 3.7 & 7.7 \\
\hline $\mathrm{C} 04$ & 0.010 & 0.0208 & 4.27 & 0.1806 & 0.0983 & 54.4 & 0.1047 & 58.0 & 3.5 & 6.3 \\
\hline $\mathrm{C} 05$ & 0.020 & 0.0208 & 3.45 & 0.1246 & 0.0741 & 59.5 & 0.0793 & 63.6 & 4.2 & 6.8 \\
\hline $\mathrm{C} 06$ & 0.020 & 0.0208 & 4.27 & 0.2424 & 0.0979 & 40.4 & 0.1139 & 47.0 & 6.6 & 15.1 \\
\hline $\mathrm{C} 07$ & 0.040 & 0.0208 & 4.07 & 0.1281 & 0.0698 & 54.5 & 0.0734 & 57.3 & 2.8 & 5.1 \\
\hline $\mathrm{C} 08$ & 0.040 & 0.0208 & 4.07 & 0.1589 & 0.0762 & 48.0 & 0.0823 & 51.8 & 3.8 & 7.7 \\
\hline $\mathrm{C} 09$ & 0.060 & 0.0208 & 4.07 & 0.1166 & 0.0653 & 56.0 & 0.0615 & 52.8 & -3.2 & -6.0 \\
\hline C10 & 0.060 & 0.0208 & 4.27 & 0.2451 & 0.0853 & 34.8 & 0.0896 & 36.6 & 1.8 & 4.9 \\
\hline C11 & 0.004 & $0.0417(1: 24)$ & 3.87 & 0.2316 & 0.1488 & 64.2 & 0.1539 & 66.4 & 2.2 & 3.4 \\
\hline C12 & 0.004 & 0.0417 & 3.21 & 0.1439 & 0.1182 & 82.1 & 0.1194 & 83.0 & 0.8 & 1.0 \\
\hline C13 & 0.010 & 0.0417 & 2.84 & 0.1433 & 0.1133 & 79.1 & 0.1145 & 79.9 & 0.9 & 1.1 \\
\hline C14 & 0.010 & 0.0417 & 3.37 & 0.2320 & 0.1369 & 59.0 & 0.1436 & 61.9 & 2.9 & 4.8 \\
\hline C15 & 0.020 & 0.0417 & 2.97 & 0.2433 & 0.1215 & 49.9 & 0.1359 & 55.9 & 5.9 & 11.2 \\
\hline C16 & 0.020 & 0.0417 & 2.28 & 0.1031 & 0.0870 & 84.4 & 0.0886 & 86.0 & 1.6 & 1.9 \\
\hline C17 & 0.050 & 0.0417 & 2.16 & 0.1724 & 0.0874 & 50.7 & 0.0983 & 57.0 & 6.3 & 11.7 \\
\hline C18 & 0.050 & 0.0417 & 3.09 & 0.2381 & 0.0940 & 39.5 & 0.1255 & 52.7 & 13.2 & 28.7 \\
\hline C19 & 0.070 & 0.0208 & 4.07 & 0.1542 & 0.0700 & 45.4 & 0.0682 & 44.2 & -1.2 & -2.6 \\
\hline $\mathrm{C} 20$ & 0.070 & 0.0417 & 3.05 & 0.1535 & 0.0803 & 52.3 & 0.0927 & 60.4 & 8.1 & 14.3 \\
\hline
\end{tabular}

Note: $S_{0}(-)$ is the road longitudinal slope, $S_{x}(-)$ is the road cross slope, $T(\mathrm{~m})$ is the upstream flow spread width, $Q_{\text {in }}\left(\mathrm{m}^{3} / \mathrm{s}\right)$ is the upstream inflow rate, $Q_{\text {cio }}\left(\mathrm{m}^{3} / \mathrm{s}\right)$ is the observed curb inlet intercepted flow rate, $E_{\text {cio }}(\%)$ is the observed curb inlet intercepted efficiency, $Q_{c i s}\left(\mathrm{~m}^{3} / \mathrm{s}\right)$ is the simulated curb inlet intercepted flow rate, $E_{c i s}(\%)$ is the simulated curb inlet intercepted efficiency, $\Delta E(\%)$ is the difference of the simulated intercepted efficiency $=E_{c i s}-$ $E_{c i o}, P D_{E}(\%)$ is the percent difference of the simulated intercepted efficiency $=\left(E_{c i s}-E_{c i o}\right) /\left[\left(E_{c i s}+E_{c i o}\right) / 2\right] \times 100 \%$.

Table 3 shows that the simulated intercepted flows and inlet efficiencies of type $\mathrm{C}$ curb inlets on the road surfaces with different longitudinal and cross slopes have great consistency with the observed 
results from the laboratory experiments conducted by Hammonds and Holley [36]. The coefficient of determination $\left(R^{2}\right)$ of the linear relationship between the simulated and observed curb inlet interception efficiencies was 0.94 . The high $R^{2}$ value with lower differences $(\Delta E)$ is evidence to support that the FullSWOF-ZG model, which predicted the curb inlet interception efficiency with good performance.

The differences of the simulated and observed interception efficiencies $(\Delta E)$ ranged from $-3.2 \%$ to $13.2 \%$, with an average \pm standard deviation of $3.5 \pm 3.5 \%$. The percent differences $\left(P D_{E}\right)$ of the simulated and observed intercepted efficiencies ranged from $-6.0 \%$ to $28.7 \%$, with an average \pm standard deviation of $6.6 \pm 7.3 \%$. In a previous study by Fang et al. [48], a three-dimensional fluid simulation software, FLOW-3D, was applied to simulate complex 3D shallow flow over the drainage pavement and flow leaving through type $C$ and type $D$ inlets. The differences $(\Delta E)$ ranged from $-7.0 \%$ to $17.6 \%$, with an average \pm standard deviation of $1.0 \pm 4.87 \%$ for type $C$ cases in their 3D simulations. The percent differences $\left(P D_{E}\right)$ for Fang's study ranged from $-19.7 \%$ to $6.1 \%$, with an average \pm standard deviation of $-0.8 \pm 5.7 \%$. These 2D SWEs models using the FullSWOF-ZG program were almost as good as the FLOW-3D models used in the previous study when trying to simulate the interception efficiency of the type $C$ curb inlet under different operation conditions. The results for all 20 modeling cases (Table 3) showed that the FullSWOF-ZG program was not only able to simulate the complicated flow over type $C$ curb inlets, but also predicted the curb inlet interception efficiency well.

\subsection{Results of Rd and RBS Modeling Cases}

\subsubsection{Example Modeling Results}

As an example of modeling results for the RBS systems, the performance of the case, RBS19, was first evaluated and compared with the modeling case, Rd19, that has no curb inlet. Figure 6 shows the simulated hydrographs for the Rd19 and RBS19 cases, the ponding depth in the RBS, infiltration rate, and cumulative infiltration depth for the RBS19 case (Table 1). A summary of the results for all modeling cases for the road-only and the RBS is given in Tables 4 and 5, respectively. Figure 6a shows the rainfall intensity over $20 \mathrm{~min}$, hydrographs of the bypass flow $\left(Q_{b p}\right)$, and the flow into the road grate inlet $\left(Q_{r g}\right)$ of the 30 min simulation period. The runoff generated from the road surface took $32 \mathrm{~s}$ to reach the grate inlet, the discharge into the grate inlet then increased rapidly to a $98 \%$ peak in 85 $\mathrm{s}$, and reached the equilibrium discharge of $11.96 \mathrm{~L} / \mathrm{s}$ at $180 \mathrm{~s}$ under the constant rainfall. The grate inlet discharge took about $300 \mathrm{~s}$ to decrease to $0 \mathrm{~L} / \mathrm{s}$ after the rainfall stopped. The rest part of the overland runoff that was not captured by the grate inlet discharges to the downstream as the bypass flow, which had a peak discharge of $1.91 \mathrm{~L} / \mathrm{s}$ at $91 \mathrm{~s}$. The sum of the peak flows of $Q_{r g}$ and $Q_{b p}$ was $13.87 \mathrm{~L} / \mathrm{s}$, which was the same as the peak discharge from the rational formula.

In comparison, Figure $6 \mathrm{~b}$ shows simulated hydrographs for $Q_{r g}, Q_{b p}$, the curb inlet intercepted flow $\left(Q_{c i}\right)$, and the overflow from the grate inlet in bioretention $\left(Q_{o g}\right)$ as well as the bioretention water depth $\left(y_{b}\right)$ of the modeling case, RBS19. The peak or equilibrium discharges of $Q_{r g}, Q_{c i}$, and $Q_{b p}$ were $8.03 \mathrm{~L} / \mathrm{s}, 4.94 \mathrm{~L} / \mathrm{s}$, and $0.50 \mathrm{~L} / \mathrm{s}$, respectively. The flow interception by the curb inlet seemed to slow down the flow a little bit to make more runoff into the grate inlet. Therefore, the sum of the peak $Q_{r g}$ and $Q_{c i}$ for RBS 19 was $12.97 \mathrm{~L} / \mathrm{s}$, which was larger than the $Q_{r g}$ of $11.96 \mathrm{~L} / \mathrm{s}$ for the Rd19 case.

Under a rainfall event, the interception efficiency, $E_{c i}$, of a curb inlet is not constant, but changes with time. For RBS19, the runoff first reached the curb inlet at $11 \mathrm{~s}$, and $E_{c i}$ was $100 \%$ when the runoff rate was small at $11 \mathrm{~s}<\mathrm{t}<31 \mathrm{~s}$, then $E_{c i}$ decreased with time and became $36.7 \%$ when $Q_{c i}$ reached the equilibrium discharge. At the end of the 40-min simulation, the runoff volume, intercepted by the curb inlet and generated from the road, can be computed and the volumetric interception efficiency was computed as $37.4 \%$ for the RBS19 case, which will be further discussed later using Table 5. Therefore, for RBS19, the grate inlet on the road still intercepted a large percent $(\sim 6 \%)$ of the incoming runoff and only about $2.6 \%$ of the runoff volume was bypassed downstream. This is important information to the road and bioretention design since many designers think the curb inlet can intercept all runoff and 
adding or keeping the grate inlet on the road is not necessary. Figure 6 also shows that the geometry of the experiment and the model allowed for a fully developed flow by the time the flow reached the inlet. This was true for all modeling cases.
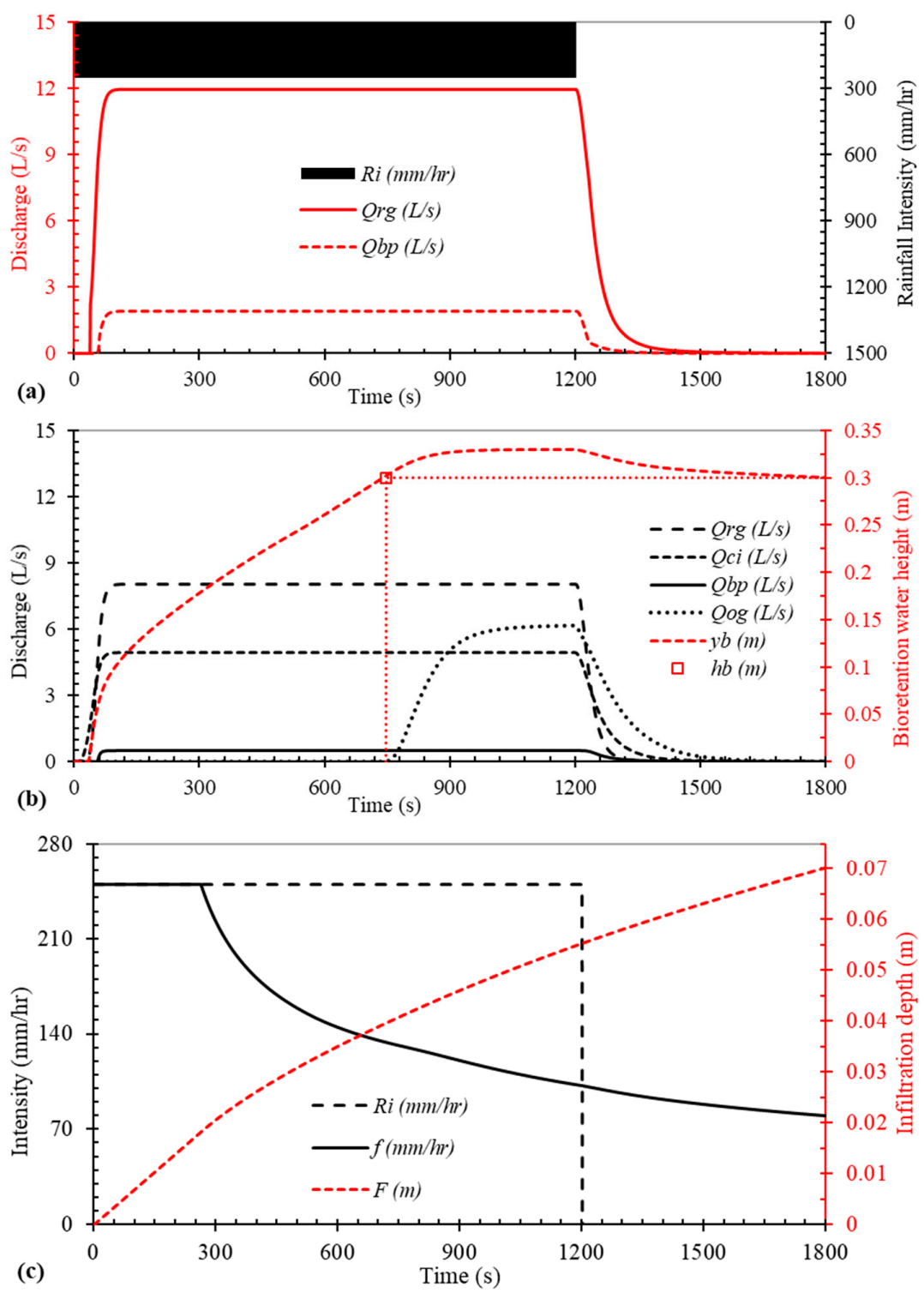

Figure 6. Simulation results of case $\operatorname{Rd} 19$ (a) and case RBS19 with an undepressed curb inlet (b,c). All symbols are defined in the text and summarized in Appendix A.

Under $250 \mathrm{~mm} / \mathrm{h}$ rainfall over $20 \mathrm{~min}$, the bioretention overflow $Q_{\text {og }}$ started at $748 \mathrm{~s}$, reached the peak discharge of $6.16 \mathrm{~L} / \mathrm{s}$ (at 1200s), and decreased after the rainfall stopped (Figure 6b). The red dash line in Figure $6 \mathrm{~b}$ shows that the ponding depth $\left(y_{b}\right)$ adjacent to the bioretention overflow grate inlet increased to become higher than the bioretention overflow height $\left(h_{b}=0.3 \mathrm{~m}\right)$ at $748 \mathrm{~s}$ and decreased to $0.3 \mathrm{~m}$ slowly after the rainfall stopped. There was a time period when $Q_{o g}$ was larger than $Q_{c i}$, which seemed impossible in the first impression. This was because the grate inlet discharge capacity was usually higher than the curb inlet capacity. In this study, the corresponding overflow weir length of the grate inlet $[2 \times(0.45+0.75) \mathrm{m}]$ was much larger than the curb inlet opening $(0.6 \mathrm{~m})$ and the hydraulic head above the grate inlet could be larger also. It was verified that the mass conservation of the runoff in the simulation domain was valid (Figure 6) and the simulated larger $Q_{o g}$ was correct. 
Table 4. Summary of simulation results of 20 road-only modeling cases (grouped by $L$ ).

\begin{tabular}{|c|c|c|c|c|c|c|c|c|c|}
\hline Case No. & $\begin{array}{c}V_{r d} \\
\left(\mathrm{~m}^{3}\right)\end{array}$ & $\begin{array}{l}V_{\text {srd }} \\
\left(\mathrm{m}^{3}\right)\end{array}$ & $\begin{array}{c}\Delta V_{r d} \\
(\%)\end{array}$ & $\begin{array}{c}V_{r g} \\
\left(\mathrm{~m}^{3}\right)\end{array}$ & $\begin{array}{l}P_{r g} \\
(\%)\end{array}$ & $\begin{array}{c}V_{b p} \\
\left(\mathrm{~m}^{3}\right)\end{array}$ & $\begin{array}{l}P_{b p} \\
(\%)\end{array}$ & $\begin{array}{l}Q_{p r g} \\
(\mathrm{~L} / \mathrm{s})\end{array}$ & $\begin{array}{l}Q_{p b p} \\
(\mathrm{~L} / \mathrm{s})\end{array}$ \\
\hline $\operatorname{Rd} 04(10 \mathrm{~m})^{1}$ & 8.33 & 8.24 & -1.02 & 8.10 & 98.3 & 0.14 & 1.7 & 6.81 & 0.13 \\
\hline Rd08 & 8.33 & 8.30 & -0.34 & 8.16 & 98.3 & 0.14 & 1.7 & 6.82 & 0.12 \\
\hline Rd12 & 8.33 & 8.31 & -0.21 & 8.06 & 97.0 & 0.25 & 3.0 & 6.74 & 0.20 \\
\hline Rd16 & 8.33 & 8.31 & -0.17 & 7.92 & 95.3 & 0.39 & 4.7 & 6.62 & 0.32 \\
\hline $\mathrm{Rd} 20$ & 8.33 & 8.31 & -0.18 & 7.67 & 92.3 & 0.64 & 7.7 & 6.42 & 0.52 \\
\hline Rd03 (20 m) & 16.66 & 16.45 & -1.25 & 14.85 & 90.3 & 1.60 & 9.7 & 12.43 & 1.45 \\
\hline Rd07 & 16.66 & 16.60 & -0.33 & 13.10 & 78.9 & 3.50 & 21.1 & 10.80 & 3.08 \\
\hline Rd11 & 16.66 & 16.63 & -0.17 & 13.81 & 83.0 & 2.82 & 17.0 & 11.43 & 2.45 \\
\hline Rd15 & 16.66 & 16.63 & -0.13 & 14.05 & 84.5 & 2.58 & 15.5 & 11.66 & 2.22 \\
\hline Rd19 & 16.66 & 16.64 & -0.11 & 14.39 & 86.5 & 2.25 & 13.5 & 11.97 & 1.91 \\
\hline Rd02 (30 m) & 24.98 & 24.49 & -2.00 & 21.52 & 87.9 & 2.97 & 12.1 & 18.01 & 2.81 \\
\hline Rd06 & 24.98 & 24.84 & -0.58 & 19.98 & 80.4 & 4.86 & 19.6 & 16.55 & 4.27 \\
\hline Rd10 & 24.98 & 24.92 & -0.24 & 17.00 & 68.2 & 7.93 & 31.8 & 13.94 & 6.88 \\
\hline $\mathrm{Rd} 14$ & 24.98 & 24.95 & -0.13 & 18.50 & 74.1 & 6.45 & 25.9 & 15.25 & 5.57 \\
\hline $\mathrm{Rd} 18$ & 24.98 & 24.96 & -0.10 & 19.18 & 76.8 & 5.78 & 23.2 & 15.86 & 4.96 \\
\hline Rd01 (40 m) & 33.31 & 32.22 & -3.28 & 22.85 & 70.9 & 9.37 & 29.1 & 19.02 & 8.73 \\
\hline Rd05 & 33.31 & 33.02 & -0.88 & 21.87 & 66.2 & 11.15 & 33.8 & 17.97 & 9.79 \\
\hline Rd09 & 33.31 & 33.16 & -0.44 & 17.71 & 53.4 & 15.45 & 46.6 & 14.38 & 13.38 \\
\hline $\mathrm{Rd} 13$ & 33.31 & 33.24 & -0.22 & 20.61 & 62.0 & 12.62 & 38.0 & 16.87 & 10.89 \\
\hline Rd17 & 33.31 & 33.27 & -0.13 & 22.96 & 69.0 & 10.31 & 31.0 & 18.89 & 8.87 \\
\hline
\end{tabular}

Note: ${ }^{1}$-the road length, $L$, is given in brackets and there is the same length for other modeling cases in the same group, $V_{r d}\left(\mathrm{~m}^{3}\right)$ is the total rainfall volume fell on the road surface, $V_{r g}\left(\mathrm{~m}^{3}\right)$ is the runoff volume captured by the road grate inlet, $V_{b p}\left(\mathrm{~m}^{3}\right)$ is the bypass runoff volume (to the road downstream), $P_{r g}(\%)$ is the percent of runoff captured by the grate inlet $=V_{r g} /\left(V_{r g}+V_{b p}\right)=V_{r g} / V_{s r d}, P_{b p}(\%)$ is the percent of the bypass runoff $=V_{b p} / V_{s r d}$, $\Delta V_{r d}(\%)$ is the percent difference of the simulated runoff volume $=\left(V_{s r d}-V_{r d}\right) / V_{r d} \times 100 \%, Q_{r r g}(\mathrm{~L} / \mathrm{s})$ is the peak discharge of the runoff captured by the road grade inlet, $Q_{p b p}(\mathrm{~L} / \mathrm{s})$ is the peak discharge of the bypass runoff.

Table 5. Simulation results of road-bioretention cases (grouped by $L$ ).

\begin{tabular}{|c|c|c|c|c|c|c|c|c|c|c|c|c|c|}
\hline Case No. & $\begin{array}{c}V_{c i} \\
\left(\mathrm{~m}^{3}\right)\end{array}$ & $\begin{array}{l}P_{c i} \\
(\%)\end{array}$ & $\begin{array}{c}V_{r g} \\
\left(\mathrm{~m}^{3}\right)\end{array}$ & $\begin{array}{l}P_{r g} \\
(\%)\end{array}$ & $\begin{array}{c}V_{b p} \\
\left(\mathrm{~m}^{3}\right)\end{array}$ & $\begin{array}{l}P_{b p} \\
(\%)\end{array}$ & $\begin{array}{c}V_{r b} \\
\left(\mathrm{~m}^{3}\right)\end{array}$ & $\begin{array}{c}V_{i n f} \\
\left(\mathrm{~m}^{3}\right)\end{array}$ & $\begin{array}{l}V_{b o g} \\
\left(\mathrm{~m}^{3}\right)\end{array}$ & $\begin{array}{l}V_{\text {bio }} \\
\left(\mathrm{m}^{3}\right)\end{array}$ & $\begin{array}{l}\Delta V \\
(\%)\end{array}$ & $\begin{array}{c}\Delta V_{r d} \\
(\%)\end{array}$ & $\begin{array}{c}\Delta V_{r b} \\
(\%)\end{array}$ \\
\hline $\operatorname{RBS04}(10 \mathrm{~m})^{1}$ & 3.30 & 40.8 & 4.76 & 58.9 & 0.02 & 0.3 & 0.83 & 1.24 & 0.00 & 3.13 & 0.0 & -2.9 & 5.8 \\
\hline RBS12 & 3.22 & 39.9 & 4.62 & 57.2 & 0.23 & 2.9 & 0.83 & 1.24 & 0.00 & 3.06 & 0.0 & -3.0 & 6.1 \\
\hline RBS16 & 3.27 & 40.5 & 4.42 & 54.7 & 0.39 & 4.8 & 0.83 & 1.25 & 0.00 & 3.10 & 0.0 & -3.0 & 5.9 \\
\hline RBS20 & 3.21 & 39.8 & 4.22 & 52.3 & 0.64 & 8.0 & 0.83 & 1.24 & 0.00 & 3.05 & 0.0 & -3.0 & 6.0 \\
\hline RBS07 & 5.85 & 36.1 & 9.89 & 61.1 & 0.44 & 2.7 & 1.67 & 1.63 & 1.03 & 5.33 & 0.0 & -2.8 & 6.3 \\
\hline RBS11 & 6.09 & 37.7 & 9.76 & 60.4 & 0.32 & 2.0 & 1.67 & 1.62 & 1.73 & 4.89 & 0.0 & -2.9 & 6.3 \\
\hline RBS15 & 5.99 & 37.1 & 9.76 & 60.4 & 0.41 & 2.6 & 1.67 & 1.61 & 2.09 & 4.45 & 0.0 & -3.0 & 6.4 \\
\hline RBS19 & 6.04 & 37.4 & 9.50 & 58.8 & 0.61 & 3.8 & 1.67 & 1.58 & 2.82 & 3.80 & 0.0 & -3.0 & 6.5 \\
\hline RBS02 (30 m) & 9.24 & 38.0 & 14.28 & 58.7 & 0.80 & 3.3 & 2.50 & 2.70 & 2.66 & 7.03 & 0.0 & -2.6 & 5.5 \\
\hline RBS06 & 9.13 & 37.5 & 13.61 & 56.0 & 1.59 & 6.5 & 2.50 & 2.65 & 3.72 & 5.91 & 0.0 & -2.6 & 5.6 \\
\hline RBS01 (40 m) & 12.18 & 37.5 & 16.87 & 52.0 & 3.40 & 10.5 & 3.33 & 4.28 & 5.01 & 7.06 & -0.1 & -2.6 & 5.4 \\
\hline RBS05 & 12.47 & 38.4 & 15.81 & 48.7 & 4.19 & 12.9 & 3.33 & 4.12 & 7.45 & 5.07 & 0.0 & -2.5 & 5.2 \\
\hline RBS09 & 12.96 & 39.9 & 15.64 & 48.2 & 3.87 & 11.9 & 3.33 & 3.85 & 9.85 & 3.43 & 0.0 & -2.5 & 5.1 \\
\hline RBS13 & 14.75 & 45.4 & 14.34 & 44.2 & 3.37 & 10.4 & 3.33 & 3.42 & 13.09 & 2.42 & 0.0 & -2.6 & 4.7 \\
\hline RBS17 & 15.72 & 48.4 & 14.67 & 45.2 & 2.06 & 6.3 & 3.33 & 3.09 & 15.14 & 1.68 & 0.0 & -2.6 & 4.5 \\
\hline
\end{tabular}

Note: ${ }^{1}$-the road length, $L$, is given in brackets and there is the same length for other modeling cases in the same group, $V_{c i}\left(\mathrm{~m}^{3}\right)$ is the runoff volume intercepted by the curb inlet, $V_{r g}\left(\mathrm{~m}^{3}\right)$ is the runoff volume captured by the road grate inlet, $V_{b p}\left(\mathrm{~m}^{3}\right)$ is the bypass runoff volume, $P_{c i}(\%)$ is the percentage of the total runoff volume that is intercepted by the curb inlet $\left(V_{c i} / V_{r d}\right), P_{r g}(\%)$ is the road grate inlet captured runoff percentage, $P_{b p}(\%)$ is the road end bypass runoff percentage, $V_{r b}\left(\mathrm{~m}^{3}\right)$ is the runoff generated on the bioretention surface from the rainfall, $V_{\text {inf }}\left(\mathrm{m}^{3}\right)$ is the bioretention infiltrated runoff volume, $V_{b o g}\left(\mathrm{~m}^{3}\right)$ is the bioretention overflow grate inlet discharge volume, $V_{\text {bio }}\left(\mathrm{m}^{3}\right)$ is the runoff ponded in bioretention at the end of the simulation, $\Delta V(\%)$ is the runoff volume percent difference of the whole simulation domain $=\left(V_{r g}+V_{b p}+V_{i n f}+V_{b o g}+V_{b i o}-V_{r d}-V_{r b}\right) /\left(V_{r d}+V_{r b}\right) \times 100 \%, \Delta V_{r d}$ $(\%)$ is the runoff volume percent difference of the road surface $=\left(V_{c i}+V_{b p}+V_{r g}-V_{r d}\right) / V_{r d} \times 100 \%, \Delta V_{r b}(\%)$ is the runoff volume percent difference of the bioretention cell $=\left(V_{i n f}+V_{b o g}+V_{b i o}-V_{c i}-V_{r b}\right) /\left(V_{c i}+V_{r b}\right) \times 100 \%$, $P_{\text {inf }}(\%)$ is the infiltrated runoff percentage $=V_{\text {inf }} /\left(V_{c i}+V_{r b}\right) \times 100 \%$. 
Figure $6 c$ shows the bioretention infiltration rate $(f)$ and cumulative infiltration $(F)$ over time. The infiltration rate was calculated using the Green-Ampt method in FullSWOF-ZG, which considers the soil infiltration parameters, runoff ponding depth, and rainfall intensity $\left(R_{i}\right)$ at every time step. The bioretention infiltration rate was equal to the rainfall intensity, $R_{i}$, when the calculated soil infiltration capacity was larger than $R_{i}$. The infiltration rate started to decrease at $263 \mathrm{~s}$ and decreased to $80.1 \mathrm{~mm} / \mathrm{h}$ at the end of the simulation. The cumulative infiltration, $F$, kept increasing during the simulation period and reached $0.07 \mathrm{~m}$ at $30 \mathrm{~min}$, which seemed small, but the infiltration continued at $\sim 80 \mathrm{~mm} / \mathrm{h}$ to gradually deplete all ponding water in the bioretention cell. The heavy rainfall $(250 \mathrm{~mm} / \mathrm{h})$ over $20 \mathrm{~min}$ was used for the simulation in order to generate the overflow in the grate inlet at the RBS so that FullSWOF-ZG was fully tested.

\subsubsection{Modeling Results for Road-Only (Rd) Cases}

Modeling results for 20 road-only cases are first presented in Figure 7a and summarized in Table 4 to compare them with modeling results for the road-bioretention cases (Figure 7b, Tables 5 and 6) in the next section. For the road-only cases, the rainfall volume, $V_{r d}$, was transformed into the runoff volume captured by the road grate inlet $\left(V_{r g}\right)$ and the bypass runoff volume $\left(V_{b p}\right)$. The percent differences $\left(\Delta V_{r d}\right)$ between the simulated runoff volume, $V_{s r d}=V_{r g}+V_{b p}$, and the rainfall volume $V_{r d}$ for 20 road-only cases ranged from $-3.3 \%$ to $0.1 \%$. The average \pm standard deviation of $\Delta V_{r d}$ was $-0.6 \pm 0.8 \%$ for 20 road-only cases (Table 4 ), which indicated FullSWOF-ZG had a higher accuracy in mass balance. These 20 modeling cases were regrouped into five groups (by alternating two colors in Table 4): The road length $L$ decreased from $40 \mathrm{~m}$ to $10 \mathrm{~m}$ as the modeling case number increased when $S_{0}$ is the same in each group (Table 1 ). Since the same rainfall was used for all modeling cases, all runoff volumes decreased with the decrease of the road length (Table 4), e.g., $V_{r g}$ decreased from $22.96 \mathrm{~m}^{3}(\operatorname{Rd} 17, L=40 \mathrm{~m})$ to $7.67 \mathrm{~m}^{3}\left(\operatorname{Rd} 20, L=10 \mathrm{~m}\right.$ ); and the corresponding $V_{b p}$ decreased from $10.31 \mathrm{~m}^{3}$ to $0.64 \mathrm{~m}^{3}$. Because of the volume decrease or less flow velocity due to less $L$, the percent of $V_{r g}\left(P_{r g}=V_{r g} / V_{s r d}\right)$ increased with the additional influence of the increase of the cross slope, e.g., Rd01-Rd04 from 70.9\% to $98.3 \%$ (Figure 7a). The percent of $V_{r g}$ ranged from $53.4 \%$ (Rd09, $\left.S_{x}=2 \%\right)$ to $98.3 \%\left(\operatorname{Rd} 08, S_{x}=4 \%\right)$, with an average \pm standard deviation of $80.7 \pm 21.5 \%$. The percent of $V_{b p}\left(P_{b p}=V_{b p} / V_{s r d}\right)$ ranged from $1.7 \%(\operatorname{Rd} 08)$ to $46.6 \%(\operatorname{Rd} 09)$, with an average \pm standard deviation of $19.3 \pm 13.0 \%$. The relatively large variations of $P_{r g}$ and $P_{b p}$ were due to the change of the road length or upstream inflow.

Table 6. Mean and standard deviation (numbers inside brackets) of parameters calculated from each of the five road-bioretention cases with the same $L(10 \mathrm{~m}-40 \mathrm{~m})$.

\begin{tabular}{|c|c|c|c|c|c|c|c|c|c|c|}
\hline Length $(L)$ & $\begin{array}{c}V_{c i} \\
\left(\mathrm{~m}^{3}\right)\end{array}$ & $\begin{array}{l}P_{c i} \\
(\%)\end{array}$ & $\begin{array}{c}V_{r g} \\
\left(\mathrm{~m}^{3}\right)\end{array}$ & $\begin{array}{l}P_{r g} \\
(\%)\end{array}$ & $\begin{array}{c}V_{b p} \\
\left(\mathrm{~m}^{3}\right)\end{array}$ & $\begin{array}{l}P_{b p} \\
(\%)\end{array}$ & $\begin{array}{c}V_{r b} \\
\left(\mathrm{~m}^{3}\right)\end{array}$ & $\begin{array}{c}V_{i n f} \\
\left(\mathrm{~m}^{3}\right)\end{array}$ & $\begin{array}{l}V_{b o g} \\
\left(\mathrm{~m}^{3}\right)\end{array}$ & $\begin{array}{l}V_{b i o} \\
\left(\mathrm{~m}^{3}\right)\end{array}$ \\
\hline $10 \mathrm{~m} \mathrm{RBS}^{1}$ & $\begin{array}{c}3.27 \\
(0.05)\end{array}$ & $\begin{array}{l}40.5 \\
(0.6)\end{array}$ & $\begin{array}{c}4.53 \\
(0.21)\end{array}$ & $\begin{array}{l}56.1 \\
(2.6)\end{array}$ & $\begin{array}{c}0.28 \\
(0.25)\end{array}$ & $\begin{array}{c}3.4 \\
(3.1)\end{array}$ & $\begin{array}{c}0.83 \\
(0.00)\end{array}$ & $\begin{array}{c}1.24 \\
(0.00)\end{array}$ & $\begin{array}{c}0.00 \\
(0.00)\end{array}$ & $\begin{array}{c}3.10 \\
(0.05)\end{array}$ \\
\hline $20 \mathrm{~m} \mathrm{RBS}^{2}$ & $\begin{array}{c}5.91 \\
(0.19)\end{array}$ & $\begin{array}{l}36.6 \\
(1.2)\end{array}$ & $\begin{array}{c}9.78 \\
(0.18)\end{array}$ & $\begin{array}{l}60.5 \\
(1.1)\end{array}$ & $\begin{array}{c}0.48 \\
(0.12)\end{array}$ & $\begin{array}{l}2.95 \\
(0.8)\end{array}$ & $\begin{array}{c}1.67 \\
(0.00)\end{array}$ & $\begin{array}{c}1.61 \\
(0.02)\end{array}$ & $\begin{array}{c}1.59 \\
(0.98)\end{array}$ & $\begin{array}{c}4.86 \\
(0.78)\end{array}$ \\
\hline $30 \mathrm{~m} \mathrm{RBS}^{3}$ & $\begin{array}{c}9.94 \\
(0.74)\end{array}$ & $\begin{array}{c}40.9 \\
(3.07)\end{array}$ & $\begin{array}{l}13.19 \\
(0.74)\end{array}$ & $\begin{array}{l}54.3 \\
(3.0)\end{array}$ & $\begin{array}{c}1.17 \\
(0.42)\end{array}$ & $\begin{array}{c}4.8 \\
(1.7)\end{array}$ & $\begin{array}{c}2.50 \\
(0.00)\end{array}$ & $\begin{array}{c}2.56 \\
(0.16)\end{array}$ & $\begin{array}{c}5.62 \\
(2.48)\end{array}$ & $\begin{array}{c}4.93 \\
(1.65)\end{array}$ \\
\hline $40 \mathrm{~m} \mathrm{RBS}^{4}$ & $\begin{array}{l}13.62 \\
(1.54)\end{array}$ & $\begin{array}{c}42.0 \\
(4.76)\end{array}$ & $\begin{array}{l}15.46 \\
(1.00)\end{array}$ & $\begin{array}{l}47.6 \\
(3.1)\end{array}$ & $\begin{array}{c}3.38 \\
(0.81)\end{array}$ & $\begin{array}{l}10.4 \\
(2.5)\end{array}$ & $\begin{array}{c}3.33 \\
(0.00)\end{array}$ & $\begin{array}{c}3.75 \\
(0.50)\end{array}$ & $\begin{array}{l}10.11 \\
(4.10)\end{array}$ & $\begin{array}{c}3.93 \\
(2.16)\end{array}$ \\
\hline
\end{tabular}

Note: ${ }^{1}$ for RBS04, 08, 12, 16, and 20; ${ }^{2}$ for RBS03, 07, 11, 15, and 19; ${ }^{3}$ for RBS02, 06, 10, 14, and 18; and ${ }^{4}$ for RBS 01 , $05,09,13$, and 17.

If sorting the modeling cases by the road length, $L$ (Table 4 ), the average $P_{r g}$ for the same $L$ cases decreased from $96.2 \%$ to $64.3 \%$ for $L$ increases from 10 to $40 \mathrm{~m}$, but the standard deviation from the mean increased from $2.5 \%$ to $7.0 \%$. Therefore, $L$ had more influence on $P_{r g}$ than $S_{0}$ did. When $L$ was 
smaller, the incoming runoff from the upstream road was small, more runoff as intercepted by the grate inlet, and less runoff was bypassed downstream. Only 20 individual road-only cases $\left(4 L \times 5 S_{0}\right)$ were modeled here; when $S_{0}$ was increased, the cross slope, $S_{x}$, was also increased to allow and guide more runoff to the grate inlet. $S_{x}$ ranged from $3.0 \%-6.5 \%$ at $L=10 \mathrm{~m}$ to $1.0 \%-4.0 \%$ at $L=40 \mathrm{~m}$ (Table 1 ). For Rd09, both $V_{b p}$ and $P_{b p}$ were the highest and indicated a high potential of the local flooding on the road. For all road-only cases, the peak discharges of the grate inlet $\left(Q_{p r g}\right)$ were $6.68 \pm 0.17 \mathrm{~L} / \mathrm{s}$ for the $L=10 \mathrm{~m}$ group, $11.66 \pm 0.61 \mathrm{~L} / \mathrm{s}$ for the $L=20 \mathrm{~m}$ group, $15.92 \pm 1.51 \mathrm{~L} / \mathrm{s}$ for the $L=30 \mathrm{~m}$ group, and $17.43 \pm 1.91 \mathrm{~L} / \mathrm{s}$ for the $L=40 \mathrm{~m}$ group. The peak discharges of the bypass flow $\left(Q_{p b p}\right)$ were 0.26 $\pm 0.17 \mathrm{~L} / \mathrm{s}$ for the $L=10 \mathrm{~m}$ group, $2.22 \pm 0.61 \mathrm{~L} / \mathrm{s}$ for the $L=20 \mathrm{~m}$ group, $4.90 \pm 1.51 \mathrm{~L} / \mathrm{s}$ for the $L=30$ $\mathrm{m}$ group, and $10.33 \pm 1.91 \mathrm{~L} / \mathrm{s}$ for the $L=40 \mathrm{~m}$ group. Both $Q_{p r g}$ and $Q_{p b p}$ increased with the increase of the catchment length.

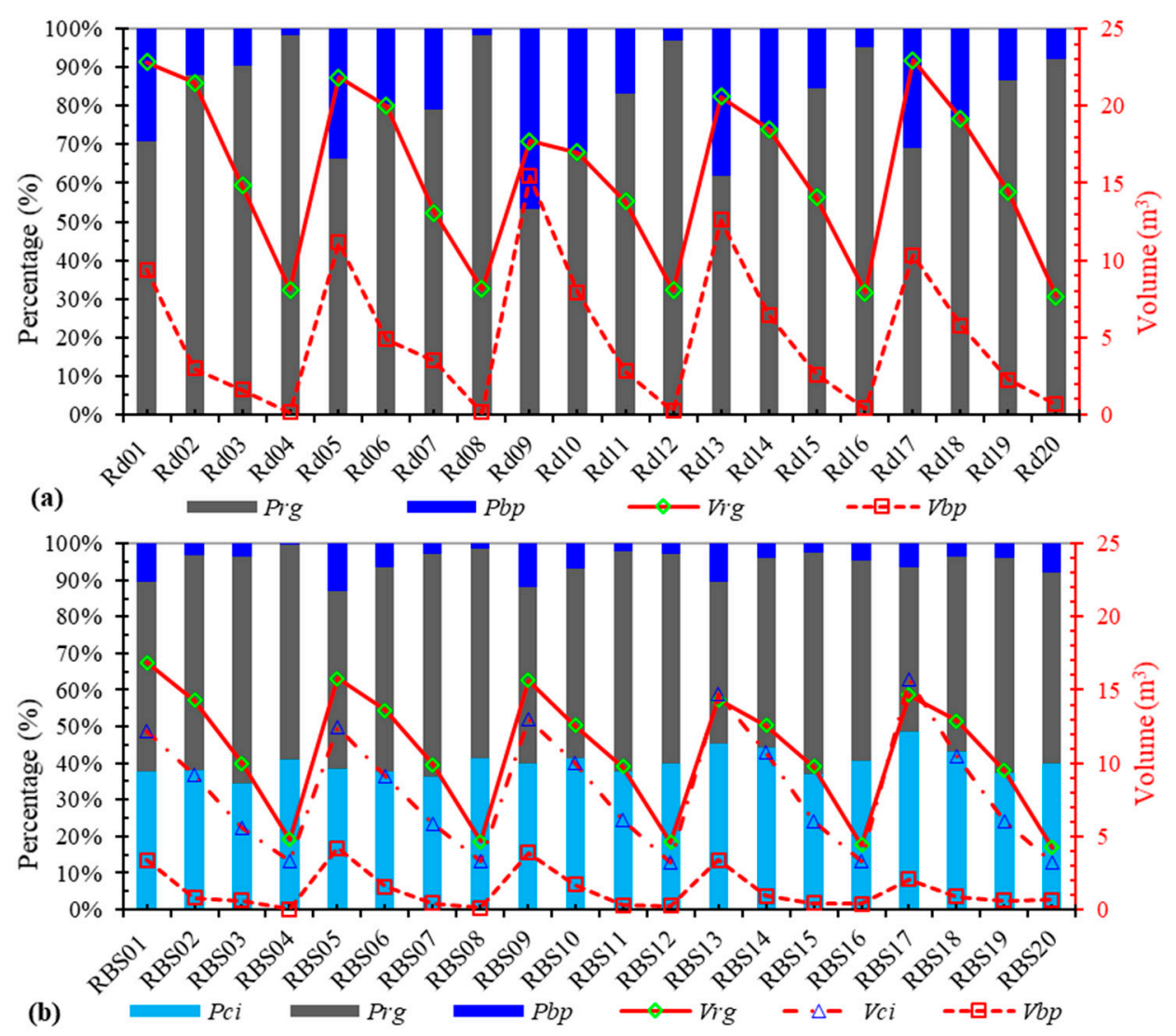

Figure 7. Runoff volumes and corresponding percentages captured by the road grate inlet $\left(V_{r g}\right.$ and $\left.P_{r g}\right)$, bypassed downstream $\left(V_{b p}\right.$ and $\left.P_{b p}\right)$ for (a) 20 road-only (Rd01-Rd20) and (b) 20 RBS modeling cases, and (b) intercepted by the curb inlet $\left(V_{c i}\right.$ and $\left.P_{c i}\right)$ for RBS modeling cases. Percentages are shown as a $100 \%$ stacked column diagram using a major $y$-axis and volumes $\left(\mathrm{m}^{3}\right)$ are shown as lines with symbols using a secondary $y$-axis.

\subsubsection{Modeling Results for Road-Bioretention Strip (RBS) Cases}

\section{Mass Balance on the Road with a Curb Inlet}

First, we studied the mass (i.e., runoff volume) balance or redistribution on the road with a curb inlet for the RBS, which was compared with the road-only cases. Results are summarized in columns 2 to 7 in Table 5 and plotted on Figure $7 \mathrm{~b}$. For the corresponding 20 bioretention modeling cases (Figure $7 \mathrm{~b}$ ), a part of the road runoff $\left(V_{s r d}\right)$ was intercepted by the curb inlet $\left(V_{c i}\right)$, resulting in a reduction of the runoff incepted by the road grate inlet $\left(V_{r g}\right)$ and bypass runoff $\left(V_{b p}\right)$. For the 20 RBS cases (Table 5), $V_{c i}$ increased from $3.27 \pm 0.05 \mathrm{~m}^{3}(L=10 \mathrm{~m})$ to $13.6 \pm 1.54 \mathrm{~m}^{3}(L=40 \mathrm{~m})$ (Table 6), 
but the percentage $\left(P_{c i}=V_{c i} / V_{s r d}=V_{c i} /\left(V_{c i}+V_{r g}+V_{b p}\right)\right)$ of runoff volume intercepted by the curb inlet (or curb inlet efficiency by volume) was similar: $40.0 \pm 3.3 \%$. This was because the curb inlet length, $L_{c i}$, was also increased from $0.45 \mathrm{~m}$ to $1.2 \mathrm{~m}$ for $L=10-40 \mathrm{~m}$. The corresponding runoff volume $\left(V_{r g}\right)$ captured by the road grate inlet increased from $4.53 \pm 0.21 \mathrm{~m}^{3}(L=10 \mathrm{~m})$ to $15.46 \pm 1.00 \mathrm{~m}^{3}$ $(L=40 \mathrm{~m})$; the bypass runoff volume $\left(V_{b p}\right)$ from $0.28 \pm 0.25 \mathrm{~m}^{3}$ to $3.38 \pm 0.81 \mathrm{~m}^{3}$. The percentage of the runoff captured by the grate inlet on the road $\left(P_{r g}=V_{r g} / V_{s r d}\right)$ decreased from $56.1 \pm 2.6 \%(L=10 \mathrm{~m})$ to $47.6 \pm 3.1 \%(L=40 \mathrm{~m})$, with an overall average \pm standard deviation of $54.6 \pm 5.2 \%$. Due to the curb inlet interception, each RBS system diverted a part of the runoff from the impervious road to the bioretention strip for infiltration and treatment (e.g., to allow sediments to settle and improve water quality), therefore, less runoff flowed into the grate inlet on the road, and then the $P_{r g}$ for the RBS (Table 5) was always smaller than for the corresponding road-only case (Table 4). The differences of $P_{r g}$ between the road-only and corresponding RBS modeling cases ranged from $5.2 \%-40.8 \%$, with an average difference of $26.0 \pm 9.6 \%$.

For all RBS cases under $250 \mathrm{~mm} / \mathrm{h}$ rainfall, the road surface runoff was not be $100 \%$ intercepted by the curb inlet, which indicated that the curb inlet was the bottleneck of the RBS system and impeded the runoff flowing into the bioretention strip for detention and infiltration to improve the stormwater quality. Therefore, the grate inlet was necessary to capture the road surface runoff and discharge into an underground drainage pipe to relieve road local flood inundation and ensure traffic safety. The bypass runoff percentage, $P_{b p}$, for the RBS cases (Figure 7 and Table 5) ranged from $0.3 \%$ (RBS04) to $12.9 \%$ (RBS05), with an average \pm standard deviation of $5.4 \pm 3.6 \%$. The $V_{b p}$ and $P_{b p}$ for all RBS cases (Table 5) were lower than them for the corresponding road-only cases (Table 4), which means the curb inlet and grate inlet combination was more efficient than the grate inlet only for intercepting the road surface runoff. The mass balance as percent differences of the whole simulation domain $(\Delta V)$, on the road $\left(\Delta V_{r d}\right)$ and in the bioretention strip $\left(\Delta V_{r b}\right)$, were small (Table 5).

\section{Mass Balance in the Bioretention Strip}

The mass (i.e., runoff volume) balance or redistribution in the bioretention strip are summarized in columns 8 to 11 in Table 5. For RBS systems, the inflow to the bioretention strip included the runoff intercepted by the curb inlet $\left(V_{c i}\right)$ and generated on the bioretention surface from rainfall $\left(V_{r b}\right)$. The bioretention outflow included the infiltration $\left(V_{\text {inf }}\right)$ and the overflow through the grate inlet near the check dam (Figure 1, $V_{\text {bog }}$ in Table 5). The difference between the inflow and the outflow was the ponding volume $\left(V_{b i o}\right)$ in the bioretention strip. $V_{r b}$ was the rainfall depth $(250 \mathrm{~mm} / \mathrm{h} \times 20$ min $)$ times the area $(L \times 1 \mathrm{~m})$ of the bioretention strip and linearly increased from $0.83 \mathrm{~m}^{3}$ to $3.33 \mathrm{~m}^{3}$ for $L=10 \mathrm{~m}$ to $40 \mathrm{~m}$.

The cumulative infiltration volume of bioretention $\left(V_{\text {inf }}\right)$ was calculated (Table 5) and the mean $V_{\text {inf }}$ ranged from $1.24 \mathrm{~m}^{3}$ for the $L=10 \mathrm{~m}$ group to $3.75 \mathrm{~m}^{3}$ for the $L=40 \mathrm{~m}$ group over $40 \mathrm{~min}$ simulation periods. To understand the soil infiltration performance of the bioretention, loamy sand was used for the $L$ of $10 \mathrm{~m}$ and $40 \mathrm{~m}$ cases, sandy loam for $L$ of $20 \mathrm{~m}$ cases, and loam for $L$ of $30 \mathrm{~m}$ cases. The average and standard deviation of the infiltrated runoff percentage, i.e., $V_{i n f} /\left(V_{c i}+V_{r b}\right)$, were $30.4 \pm 0.3 \%$ for loamy sand ( $L=10 \mathrm{~m}$ group), $21.3 \pm 0.8 \%$ for sandy loam ( $L=20 \mathrm{~m}$ group), $20.7 \pm 6.5 \%$ for loam ( $L=30 \mathrm{~m}$ group), and $22.5 \pm 8.5 \%$ for loamy sand ( $L=40 \mathrm{~m}$ group).

The infiltration in the bioretention cell is influenced by the runoff inflow, the soil infiltration capacity, and the ponding depth as FullSWOF_2D considers the water depth when applying the Green-Ampt method [32]. Under small rainfall intensity and higher infiltration rate, it was possible for all runoff to infiltrate downward and the bioretention cell did not have any ponding. The infiltrated runoff volume, $V_{\text {inf, }}$, decreased from $\operatorname{RBS} 01\left(4.28 \mathrm{~m}^{3}\right)$ to $\operatorname{RBS17}\left(3.09 \mathrm{~m}^{3}\right.$, Table $5, L=40 \mathrm{~m}$ group), mainly because the smaller longitudinal slope, $S_{0}$, increased the ponding area, since $h_{b}$ and the infiltration parameters were the same for these five modeling cases. For RBS01, RBS05, and RBS09, $L \times S_{0} \leq h_{b}$, so that the maximum ponding area was $40 \mathrm{~m} \times 1 \mathrm{~m}$ (width of the bioretention strip); 
for RBS13 and RBS17, $L \times S_{0}>h_{b}$, so that the maximum ponding area was less than $40 \mathrm{~m} \times 1 \mathrm{~m}$ (only covered $28.6 \mathrm{~m}$ and $20 \mathrm{~m}$, respectively).

There was no overflow through the grate inlet in the bioretention strip for the modeling cases of $L$ $=10 \mathrm{~m}\left(V_{\text {bog }}=0\right)$ because the overflow height of the grate inlet $\left(h_{b}\right)$ was the largest $\left(0.4 \mathrm{~m}, D_{b}-0.05\right.$ in Table 1$)$, but the maximum ponding depth $\left(h_{\max }\right.$, Table 7$)$ was less than $h_{b}$ for these cases. All other three modeling groups $(L=20,30$, and $40 \mathrm{~m})$ overflowed through the grate inlet in the bioretention $\left(h_{\max }>h_{b}\right.$, Table 7). The increase of the overflow grate-inlet volume $V_{\text {bog }}$ (Table 5) was mainly because of the increase of the longitudinal slope $\left(S_{0}\right)$ when $L$ and $h_{b}$ were unchanged. The mean $V_{b o g}$ increased from $1.59 \mathrm{~m}^{3}$ ( $L=20 \mathrm{~m}$ group) to $10.11 \mathrm{~m}^{3}$ ( $L=40 \mathrm{~m}$ group) when $h_{b}$ decreased from 0.3 to $0.2 \mathrm{~m}$. This indicated that the overflow height, $h_{b}$, was a key design parameter of the RBS to retain the runoff inside the bioretention.

Table 7. Mean and standard deviation (numbers inside brackets) of additional simulation results calculated from each of the five road-bioretention cases with the same $L$ (10-40 m).

\begin{tabular}{lccccccc}
\hline Length (L) & $\begin{array}{c}h_{\text {max }} \\
(\mathbf{m})\end{array}$ & $\begin{array}{c}T_{\text {bog }} \\
(\mathbf{s})\end{array}$ & $\begin{array}{c}Q_{\text {pog }} \\
(\mathbf{L} / \mathbf{s})\end{array}$ & $\begin{array}{c}V_{p c} \\
\left(\mathbf{m}^{3}\right)\end{array}$ & $\begin{array}{c}V_{\text {bio }}(\mathbf{4 0}) / V_{p c} \\
(-)\end{array}$ & $\begin{array}{c}Q_{\text {prgb }} \\
(\mathbf{L} / \mathbf{s})\end{array}$ & $\begin{array}{c}Q_{\text {prgb }} / Q_{\text {prg }} \\
(-)\end{array}$ \\
\hline \multirow{2}{*}{$10 \mathrm{~m} \mathrm{RBS}^{1}$} & 0.36 & - & 0.00 & 4.02 & 0.77 & 3.84 & 0.57 \\
& $(0.02)$ & & $(0.00)$ & $(0.22)$ & $(0.03)$ & $(0.19)$ & $(0.02)$ \\
\hline \multirow{2}{*}{$20 \mathrm{~m} \mathrm{RBS}^{2}$} & 0.32 & 975 & 4.81 & 5.12 & 0.95 & 8.30 & 0.71 \\
& $(0.01)$ & $(188)$ & $(2.17)$ & $(0.80)$ & $(0.01)$ & $(0.19)$ & $(0.04)$ \\
\hline \multirow{2}{*}{$30 \mathrm{~m} \mathrm{RBS}^{3}$} & 0.29 & 650 & 9.43 & 5.27 & 0.93 & 11.23 & 0.71 \\
& $(0.00)$ & $(255)$ & $(1.15)$ & $(1.67)$ & $(0.02)$ & $(0.72)$ & $(0.03)$ \\
\hline \multirow{2}{*}{$40 \mathrm{~m} \mathrm{RBS}^{4}$} & 0.24 & 392 & 12.65 & 4.36 & 0.89 & 13.14 & 0.76 \\
& $(0.01)$ & $(252)$ & $(1.81)$ & $(2.22)$ & $(0.03)$ & $(0.92)$ & $(0.10)$
\end{tabular}

Note: ${ }^{1}$ for RBS04, 08, 12, 16, and 20; ${ }^{2}$ for RBS03, 07, 11, 15, and $19 ;{ }^{3}$ for RBS02, 06, 10, 14, and 18; ${ }^{4}$ for RBS01, 05, 09,13 , and $17 ; h_{\max }(\mathrm{m})$ is the maximum ponding depth (water height) in the bioretention, $T_{b o g}(\mathrm{~s})$ is the time when the bioretention overflow starts, $Q_{\text {pog }}(\mathrm{L} / \mathrm{s})$ is the bioretention overflow peak discharge, $V_{p c}\left(\mathrm{~m}^{3}\right)$ is the calculated maximum bioretention ponding volume based on bioretention-strip geometry, $V_{b i o}(40) / V_{p c}$ is the percentage of the bioretention ponding volume at the end of the 40-min simulation to the calculated bioretention ponding volume, $Q_{p r g b}(\mathrm{~L} / \mathrm{s})$ is the road grate inlet peak discharge for RBS cases, $Q_{\text {prgb }} / Q_{\text {prg }}$ is the ratio of the road grate inlet peak discharge for RBS case to corresponding Rd case.

The mean $V_{b o g}$ percentage, i.e., $V_{b o g} /\left(V_{c i}+V_{r b}\right)$, increased when $h_{b}$ decreased: $20.7 \pm 12.7 \%$ for the $L=20 \mathrm{~m}$ group $\left(h_{b}=0.30 \mathrm{~m}\right), 44.4 \pm 8.8 \%$ for the $L=30 \mathrm{~m}$ group $\left(h_{b}=0.25 \mathrm{~m}\right)$, and $58.4 \pm 10.2 \%$ for the $L=40 \mathrm{~m}$ group $\left(h_{b}=0.20 \mathrm{~m}\right)$. When $h_{b}$ was small, the grate-inlet overflow became the main mechanism to remove the extra runoff in the bioretention strip as indicated by the larger $V_{b o g}$ percentage.

The mean overflow peak discharge, $Q_{p o g}$, increased from $4.81 \mathrm{~L} / \mathrm{s}$ to $12.65 \mathrm{~L} / \mathrm{s}$ for $L=20-40 \mathrm{~m}$ groups (Table 7) when the total inflow $\left(V_{c i}+V_{r b}\right)$ increased, $h_{b}$ decreased also. The bioretention overflow-start-time, $\left(T_{b o g}\right)$ and $Q_{p o g}$, were mainly related to $V_{c i}$ and $h_{b}$. $T_{b o g}$ decreased from $974.8 \pm 188.2 \mathrm{~s}(L=20 \mathrm{~m}$ group) to $391.6 \pm 252.5 \mathrm{~s}$ ( $L=40 \mathrm{~m}$ group). The bioretention overflow was delayed when the overflow height, $h_{b}$, increased. The bioretention overflow was first projected to start at $163 \mathrm{~s}$ in the RBS17 modeling case and reached the peak discharge of $14.92 \mathrm{~L} / \mathrm{s}$. The main reason was the largest curb inlet intercepted runoff volume of RBS17 $\left(15.72 \mathrm{~m}^{3}\right)$ due to the large $L$ and $S_{x}$ and the lowest $h_{b}=0.20 \mathrm{~m}$.

For all 20 RBS cases (Table 5), the mean ponding volume in the bioretention $\left(V_{b i o}\right)$ were $3.10 \mathrm{~m}^{3}$ for the $L=10 \mathrm{~m}$ group, $4.86 \mathrm{~m}^{3}$ for the $L=20 \mathrm{~m}$ group, $4.93 \mathrm{~m}^{3}$ for the $L=30 \mathrm{~m}$ group, and $3.93 \mathrm{~m}^{3}$ for the $L=40 \mathrm{~m}$ group when the rainfall intensity was large $(250 \mathrm{~mm} / \mathrm{h}) . V_{b i o}$ is a function of time and shows the integrated/cumulative effects of different flow processes (inflow from curb inlet, outflow through the overflow grate inlet, rainfall, and infiltration). $V_{b i o}(t)$ is also related to the bioretention strip's ponding capacity, which was determined by the bioretention-strip geometry as shown in Equation (9). There are four modeling cases (RBS09, 13, 17, and 18; Table 1) with $L \times S_{0} \geq h_{b}$; therefore, the overflow height, $h_{b}$, was the only controlling factor for $V_{b i o}(t)$, independent of $L \times S_{0}$ for these four cases. 
From the beginning of the simulation, when the ponding depth was zero (more infiltration and zero runoff), $V_{b i o}(t)$ was zero. When the ponding depth increased from zero to $h_{b}, V_{b i o}(t) / V_{p c}$ increased from zero to 1.0, since $V_{p c}$ (Equation (9) is the calculated maximum bioretention ponding volume at $h_{b}$. When the overflow through the grate inlet took place in the bioretention strip, $V_{b i o}(t) / V_{p c}$ was greater than 1.0. After the rainfall stopped, eventually, $V_{b i o}(t)$ was zero when the ponding depth decreased to zero. In this study, $V_{\text {bio }}(t)$ at the end of the simulation ( $t=40 \mathrm{~min}$ ) for each RBS case is shown in Table 5 and was used to calculate the runoff-volume mass-balance percent difference $(\Delta V)$ in the whole simulation domain. These percent differences (Table 5) were very small, with an average of $-0.02 \%$, and indicated that the RBS simulation results were reasonable.

The average $V_{b i o}(40)$ percentage, $V_{b i o}(40) /\left(V_{c i}+V_{r b}\right)$ at the end of simulation, $t=40 \mathrm{~min}$, was larger when $h_{b}$ was larger: $75.6 \pm 0.2 \%$ for the $L=10 \mathrm{~m}$ group $\left(h_{b}=0.4 \mathrm{~m}\right), 64.3 \pm 11.8 \%$ for the $L=20 \mathrm{~m}$ group, $40.3 \pm 26.7 \%$ for the $L=30 \mathrm{~m}$ group, and $24.2 \pm 26.3 \%$ for the $L=40 \mathrm{~m}$ group $\left(h_{b}=0.2 \mathrm{~m}\right)$. The higher $V_{b i o}(40)$ percentage means that more runoff was ponded and waited for infiltration when the simulation ended. The ponding volume, $V_{b i o}(40)$, for each case was compared with $V_{p c}$, and the ratio ranged from 0.73 to 0.96 (Table 7).

At the end of the simulation, $V_{b i o}(40)$ was smaller than $V_{p c}$, and the mean ratios of $V_{b i o} / V_{p c}$ were $0.77-0.95$ for the changing $L$. The results in Table 7 and Equation (9) indicate that it is necessary to consider three parameters, $S_{0}, L$, and $h_{b}$, when calculating the ponding capacity of the bioretention; this was especially important in the continuous RBS system when these three parameters changed in different RBSs. In this study, the vegetation volume fraction was not considered when calculating $V_{p c}$, therefore, we need to use a safety factor to calculate the actual ponding volume based on the bioretention geometry and vegetation volume fraction when designing a continuous RBS system.

\subsection{Implications of the Simulation Results on RBS Design}

In this study, three implications can be drawn through the detailed analysis of the simulation results of the 20 RBS cases.

(1) The curb inlet could be the bottleneck of a continuous road-bioretention facility that impedes the runoff generated from the road flowing into the bioretention to infiltrate, detain (pond), and improve the stormwater quality. The analysis of 20 RBS performance indicated only $34.6-48.4 \%$ of the total runoff volume (Table 5) was intercepted by the curb inlet when the intensity was $250 \mathrm{~mm} / \mathrm{h}$ for $20 \mathrm{~min}$ and the remaining part of the runoff flowed downstream along the road, which may cause local inundation and become a safety hazard. Many bioretention system designs do not pay much attention to the curb inlet interception efficiency, but only focus on the bioretention BMP itself. It is necessary to appropriately design the curb inlet to intercept enough stormwater runoff to improve the performance of RBS based on detailed hydraulic calculations, for example, using the HEC-22 method. Equations (1)-(3) indicate that HEC-22 considers the effects of the road longitudinal slope, cross slope, surface roughness, incoming flow or spread, and the inlet length on the curb inlet interception efficiency. The HEC-22 method has been widely used in the USA for drainage inlet design, but is seldom used for designing inlets for LID facilities. The HEC-22 calculated and FullSWOF-ZG simulated curb inlet efficiencies will be compared and evaluated in a future study.

(2) Bioretention BMP is intended to detain the runoff intercepted by the inlet under frequent rainfall events (e.g., the 95th percentile rainfall), and some current practices of the RBS design in China that eliminate necessary grate inlets on the road could cause local flooding (inundation) on the road under heavy rainfall events. The analysis of 20 RBS's performances indicated that the runoff generated from the road, but could not be intercepted by the curb inlet, thus it needed to be captured by the grate inlet downstream from the curb inlet (Figure 4). In this study, the percent of runoff captured by the road grate inlet for the RBS system ranged from $44.2 \%$ to $61.7 \%$ (Table 5) under $250 \mathrm{~mm} / \mathrm{h}$ heavy rainfall over $20 \mathrm{~min}$. This indicated the importance of the grate inlet downstream of the curb inlet for the RBS system. The curb inlet intercepted the runoff for the bioretention strip and the grate inlet intercepted the bypassed flow after the curb inlet. 
The peak discharges of the road grate inlet for 20 RBS modeling cases $\left(Q_{\text {prgb }}\right.$, Table 7$)$ were compared with the corresponding $Q_{\text {prg }}$ for the road-only modeling cases. For all 20 RBS cases, the average $Q_{\text {prgb }}$ increased from $3.84 \mathrm{~L} / \mathrm{s}$ to $13.14 \mathrm{~L} / \mathrm{s}$ for an $L$ increase from 10 to $40 \mathrm{~m}$. Comparing with $Q_{p r g}$, the average ratio of $Q_{\text {prgb }} / Q_{\text {prg }}$ were from 0.57 to 0.76 for $L=10-40 \mathrm{~m}$ groups. The overall average \pm standard deviation of $Q_{p r g b} / Q_{p r g}$ for 20 modeling cases was $0.69 \pm 0.09$, which indicates that the curb inlet and grate inlet combination could reduce the road grate inlet peak discharge and help to relieve road local flood inundation. Therefore, the curb inlet and grate inlet combination greatly benefits the runoff control, local flood inundation relief, and traffic safety, especially for continuous road-bioretention. Eliminating the grate inlets on the road for the RBS system is not a recommended design practice.

(3) A safety factor should be adopted to calculate the bioretention ponding volume when designing the RBS system. The actual ponding volume should be equal to the ponding volume calculated based on the bioretention geometry $\left(V_{p c}\right)$ multiplied by the safety factor used for RBS design. The berm at the end of a bioretention cell (Figures 1 and 2) is typically to pond the runoff for infiltration and to ensure that the overflow discharges through the grate inlet rather than flowing into the bioretention downstream. For the RBS13, RBS17, and RBS18 modeling cases, $L \times S_{0}>h_{b}$, so that the maximum ponding and infiltration area was less than the total bioretention surface area (e.g., $40 \mathrm{~m} \times 1 \mathrm{~m}$ in this study), which is not a recommended design configuration for the bioretention strip. The distance between the ditch dikes should be small enough to have $L \times S_{0} \leq h_{b}$ or pond the runoff in the whole bioretention area. The bioretention ponding volume is influenced by the bioretention cells' geometry, including the length, longitudinal slope, and overflow height; it can be computed using Equation (9), but the vegetation volume fraction can be important when the vegetation density in the bioretention is very high (Figure 2a) so that a ponding volume safety factor should be introduced. The EPA-SWMM model suggests the vegetation volume fraction of $0.1-0.2$, therefore, the safety factor used for RBS design in computing the ponding volume should be $0.8-0.9$.

\section{Conclusions}

The open-source Full Shallow-Water equations for Overland Flow in the two-dimensional (FullSWOF_2D) program, which applies the uniform rainfall and infiltration parameters to the whole simulation domain, was revised to include $2 \mathrm{D}$ plane zones $(Z)$ with different rainfall and infiltration parameters and a 2D-1D grate-inlet (G) drainage module. The FullSWOF-ZG program was tested with the overland flow of eight pervious surface rainfall-runoff events and 20 impervious roads with a type $C$ curb inlet to study whether the program could accurately simulate the overland flow on a pervious and impervious surface and accurately predict the curb inlet interception efficiency. Twenty road-bioretention strip or RBS modeling cases were designed based on the commonly used parameters (longitudinal and cross slopes, curb opening length, soil infiltration parameters, the bioretention depression depth, and the overflow height) and evaluated with FullSWOF-ZG. The simulation results were analyzed and demonstrated that the RBS hydrological performance, i.e., to intercept then infiltrate the runoff, was jointly influenced by several parameters. Even if the complex relationship between the RBS performance and all input parameters were not fully explored by using only 20 cases, we suggest three main points resulting from this study. (1) The RBS's curb inlet could be the bottleneck of its hydrologic performance and should be designed to improve inlet interception efficiency, e.g., using procedures and equations in HEC-22; (2) The curb inlet and road grate inlet combination is necessary for continuous RBS because the road surface runoff could not be $100 \%$ intercepted by the curb inlet alone; and (3) it is necessary to consider the safety factor of the high-density vegetation and the relationship of overflow height, bioretention cell length, and longitudinal slope when calculating the ponding volume for the RBS design. The RBS performance evaluation and design under different rainfall distribution and intensity situations will be conducted in a future study. The performance improvement of RBS with different types of curb inlet will also be 
conducted in a future study to provide suggestions for SPC construction in China and LID practices (especially bioretention BMPs) over the world.

Author Contributions: X.L. added spatialized rainfall and infiltration modules, and 2D-1D grate inlet drainage module to the FullSWOF_2D program, conducted the simulations and analysis of the results, prepared the manuscript draft. X.F. supervised the model development, simulation runs, data analysis; and revised the manuscript. Y.G. proposed the prime idea of the paper when X.L. studied in Beijing. M.-H.L. and his graduate students collected the experimental data of pervious test cases and revised the manuscript. J.L., J.W., and G.C. provided inputs on the writing, data analysis, and revised the manuscript. All authors made contributions to the study and writing the manuscript.

Funding: The research was partially supported by the National Natural Science Foundation of China (No. 51478026), Beijing Higher Education High-Level Teachers Team Construction Program (CIT \& TCD 201704055) and Beijing University of Civil Engineering and Architecture Research Fund for Pyramid Talents Development. The author, Xiaoning Li, wishes to express his gratitude to the Chinese Scholarship Council for financial support pursuing his graduate study at Auburn University.

Conflicts of Interest: The authors declare no conflict of interest.

\section{Appendix A}

A summary of the definitions or descriptions of acronyms and symbols used in the paper is given below.

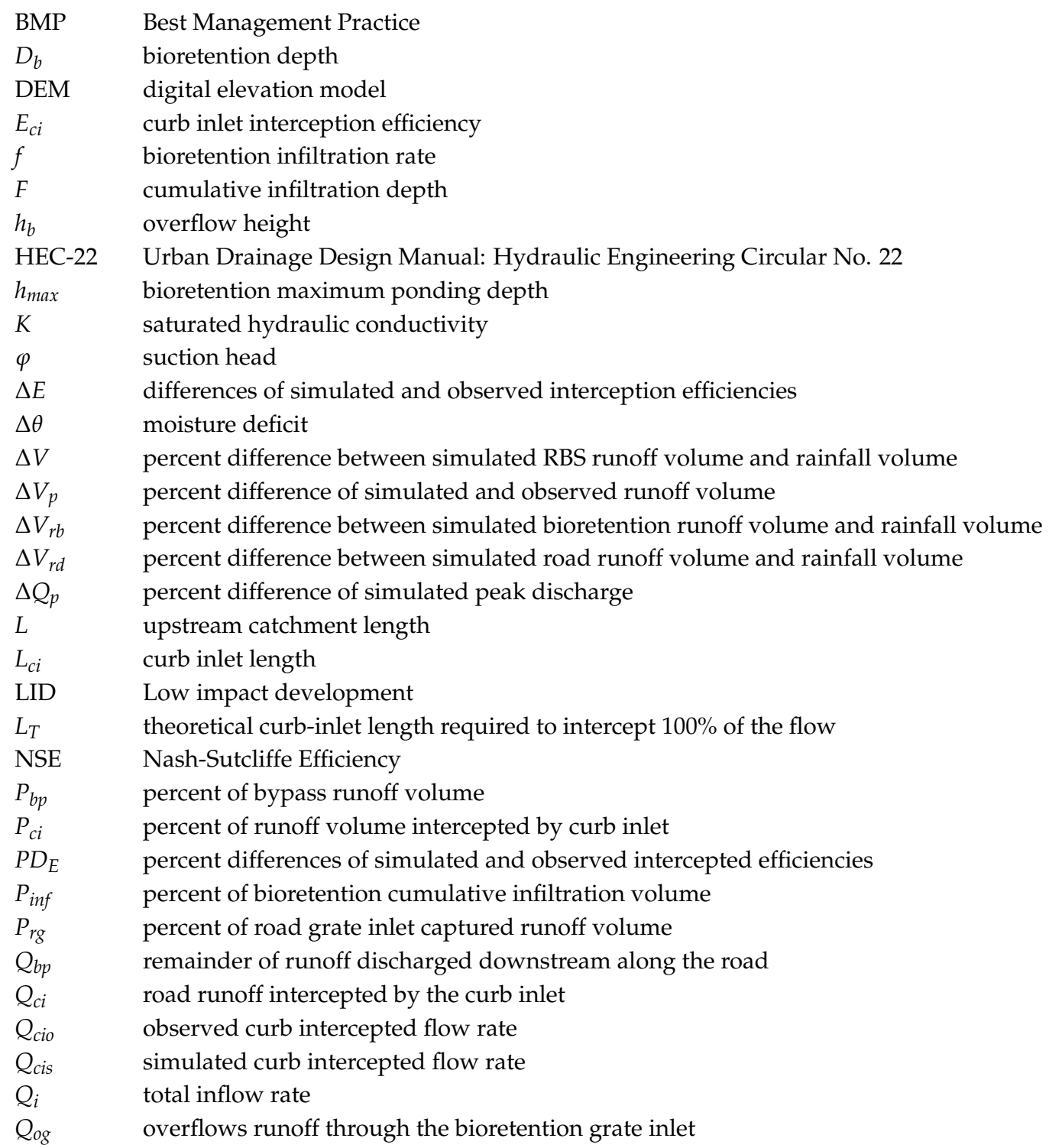




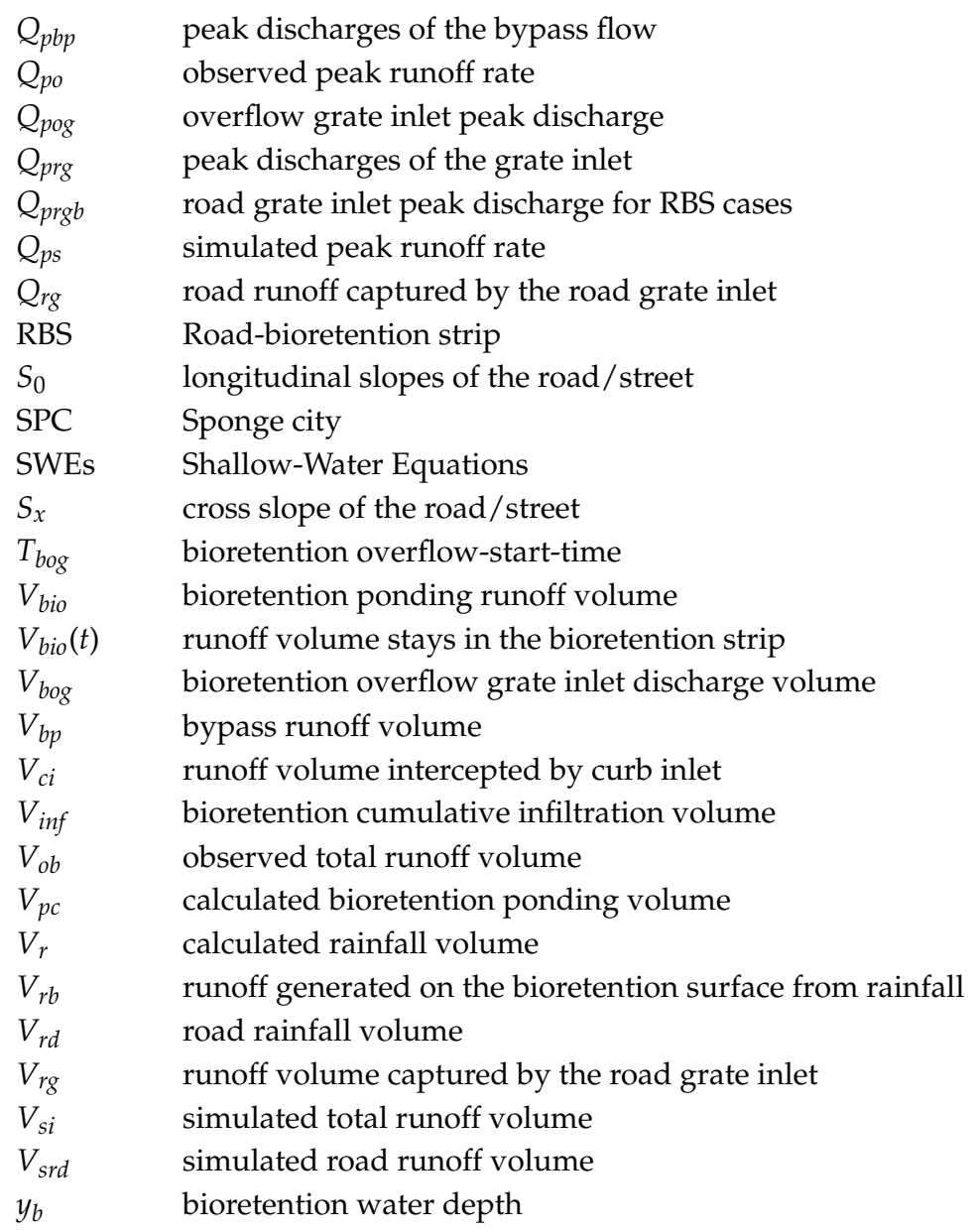

\section{References}

1. National Bureau of Statistics of China. China Statistical Yearbook-2017; China Statistics Press: Beijing, China, 2017.

2. National New-Type Urbanization Plan (2014-2020). Available online: http:/ /www.gov.cn/zhengce/201403/16/content_2640075.htm (accessed on 29 March 2018).

3. Li, H.; Ding, L.; Ren, M.; Li, C.; Wang, H. Sponge city construction in China: A survey of the challenges and opportunities. Water 2017, 9, 594. [CrossRef]

4. Brabec, E.; Schulte, S.; Richards, P.L. Impervious surfaces and water quality: A review of current literature and its implications for watershed planning. J. Plan. Lit. 2002, 16, 499-514. [CrossRef]

5. Moglen, G.E. Hydrology and impervious areas. J. Hydrol. Eng. 2009, 14, 303-304. [CrossRef]

6. Todeschini, S. Hydrologic and environmental impacts of imperviousness in an industrial catchment of northern Italy. J. Hydrol. Eng. 2016, 21, 05016013. [CrossRef]

7. Cheshmehzangi, A. China's New-Type Urbanisation Plan (NUP) and the foreseeing challenges for decarbonization of cities: A review. Energy Procedia 2016, 104, 146-152. [CrossRef]

8. Jia, H.; Wang, Z.; Yu, S.L. Opportunity and Challenge: China's Sponge City Plan. Hydrolink 2016, 4, 100-102.

9. Li, X.; Li, J.; Fang, X.; Gong, Y.; Wang, W. Case studies of the sponge city program in China. In Proceedings of the World Environmental and Water Resources Congress 2016, West Palm Beach, FL, USA, 22-26 May 2016; pp. 295-308.

10. Yu, S.; Jia, H. China's ambitious Sponge City initiative: A monumental effort for green/gray infrastructure integration. ASCE EWRI Currents 2016, 17, 8-9.

11. Prince George's County. Design Manual for Use of Bioretention in Stormwater Management; Prince George's County (MD) Government, Department of Environmental Protection; Watershed Protection Branch: Landover, MD, USA, 1993. 
12. Prince George's County. Bioretention Manual; Prince George's County (MD) Government, Department of Environmental Protection; Watershed Protection Branch: Landover, MD, USA, 2002.

13. Dietz, M.E. Low impact development practices: A review of current research and recommendations for future directions. Water Air Soil Pollut. 2007, 186, 351-363. [CrossRef]

14. Davis, A.P.; Hunt, W.F.; Traver, R.G.; Clar, M. Bioretention technology: Overview of current practice and future needs. J. Environ. Eng. 2009, 135, 109-117. [CrossRef]

15. Dietz, M.E.; Clausen, J.C. Saturation to improve pollutant retention in a rain garden. Environ. Sci. Technol. 2006, 40, 1335-1340. [CrossRef]

16. Davis, A.P. Field performance of bioretention: Hydrology impacts. J. Hydrol. Eng. 2008, 13, 90-95. [CrossRef]

17. Hunt, W.; Jarrett, A.; Smith, J.; Sharkey, L. Evaluating bioretention hydrology and nutrient removal at three field sites in North Carolina. J. Irrig. Drain. Eng. 2006, 132, 600-608. [CrossRef]

18. Passeport, E.; Hunt, W.F.; Line, D.E.; Smith, R.A.; Brown, R.A. Field study of the ability of two grassed bioretention cells to reduce storm-water runoff pollution. J. Irrig. Drain. Eng. 2009, 135, 505-510. [CrossRef]

19. Hatt, B.E.; Fletcher, T.D.; Deletic, A. Hydrologic and pollutant removal performance of stormwater biofiltration systems at the field scale. J. Hydrol. 2009, 365, 310-321. [CrossRef]

20. Chapman, C.; Horner, R.R. Performance assessment of a street-drainage bioretention system. Water Environ. Res. 2010, 82, 109-119. [CrossRef] [PubMed]

21. Li, M.-H.; Sung, C.; Kim, M.; Chu, K.-H. Assessing performance of bioretention boxes in hot and semiarid regions: Highway application pilot study. Transp. Res. Rec. 2011, 2262, 155-163. [CrossRef]

22. Trowsdale, S.A.; Simcock, R. Urban stormwater treatment using bioretention. J. Hydrol. 2011, 397, $167-174$. [CrossRef]

23. Lucke, T.; Nichols, P.W.B. The pollution removal and stormwater reduction performance of street-side bioretention basins after ten years in operation. Sci. Total Environ. 2015, 536, 784-792. [CrossRef] [PubMed]

24. Li, M.-H.; Swapp, M.; Kim, M.H.; Chu, K.-H.; Sung, C.Y. Comparing bioretention designs with and without an internal water storage layer for treating highway runoff. Water Environ. Res. 2014, 86, 387-397. [CrossRef]

25. National Association of City Transportation Officials. Urban Street Stormwater Guide; Island Press: Washington, DC, USA, 2017.

26. Ministry of Housing and Urban-Rural Development. Code for Design of Outdoor Wastewater Engineering; Ministry of Housing and Urban-Rural Development: Beijing, China, 2016; p. 15.

27. Mangangka, I.R.; Liu, A.; Egodawatta, P.; Goonetilleke, A. Performance characterisation of a stormwater treatment bioretention basin. J. Environ. Manag. 2015, 150, 173-178. [CrossRef]

28. Comport, B.C.; Thornton, C.I. Hydraulic efficiency of grate and curb inlets for urban storm drainage. J. Hydraul. Eng. 2012, 138, 878-884. [CrossRef]

29. Schalla, F.E.; Ashraf, M.; Barrett, M.E.; Hodges, B.R. Limitations of Traditional Capacity Equations for Long Curb Inlets. Transp. Res. Rec. 2017, 2638, 97-103. [CrossRef]

30. Guo, J.C. Design of street curb opening inlets using a decay-based clogging factor. J. Hydraul. Eng. 2006, 132, 1237-1241. [CrossRef]

31. Jia, H.; Wang, Z.; Zhen, X.; Clar, M.; Shaw, L.Y. China's Sponge City construction: A discussion on technical approaches. Front. Environ. Sci. Eng. 2017, 11, 18. [CrossRef]

32. Delestre, O.; Darboux, F.; James, F.; Lucas, C.; Laguerre, C.; Cordier, S. FullSWOF: A free software package for the simulation of shallow water flows. arXiv, 2014; arXiv:1401.4125.

33. Gourbesville, P.; Cunge, J.; Caignaert, G. Advances in Hydroinformatics-SIMHYDRO 2014, 1st ed.; Springer: Singapore, 2014; p. 624.

34. Leandro, J.; Martins, R. A methodology for linking 2D overland flow models with the sewer network model SWMM 5.1 based on dynamic link libraries. Water Sci. Technol. 2016, 73, 3017-3026. [CrossRef] [PubMed]

35. Liang, X. Hydraulic calculation and design optimization of curb opening in Sponge City construction (in Chinese). China Water Wastew. 2018, 34, 42-45.

36. Hammonds, M.A.; Holley, E.R. Hydraulic Characteristics of Flush Depressed Curb Inlets and Bridge Deck Drains; FHWA-TX 96-1409-1; Texas Department of Transportation: Austin, TX, USA, 1995.

37. Brown, S.; Stein, S.; Warner, J. Urban Drainage Design Manual: Hydraulic Engineering Circular No. 22; FHWA-NHI-10-009 HEC-22; National Highway Institute: Washington, DC, USA, 2009. 
38. Delaware Natural Resources and Environmental Control. Green technology: The Delaware urban runoff management approach. In Standards, Specifications and Details for Green Technology BMPs to Minimize Stormwater Impacts from Land Development; Delaware Department of Natural Resources and Environmental Control, Division of Soil and Water Conservation: Dover, Delaware, 2005; p. 93.

39. Ermilio, J.; Traver, R. Hydrologic and pollutant removal performance of a bio-infiltration BMP. In Proceedings of the World Environmental and Water Resource Congress 2006: Examining the Confluence of Environmental and Water Concerns, Omaha, NE, USA, 21-25 May 2006; pp. 1-12.

40. Barré de Saint-Venant, A.J.C. Théorie du mouvement non permanent des eaux, avec application aux crues des rivières et à l'introduction des marées dans leurs lits. Comptes Rendus des séances de l'Académie des Sciences 1871, 73, 237-240.

41. Zhang, W.; Cundy, T.W. Modeling of two-dimensional overland flow. Water Resour. Res. 1989, 25, $2019-2035$. [CrossRef]

42. Unterweger, K.; Wittmann, R.; Neumann, P.; Weinzierl, T.; Bungartz, H.-J. Integration of FullSWOF2D and PeanoClaw: Adaptivity and local time-stepping for complex overland flows. In Recent Trends in Computational Engineering-CE2014; Springer: New York, NY, USA, 2015; pp. 181-195.

43. Cordier, S.; Coullon, H.; Delestre, O.; Laguerre, C.; Le, M.H.; Pierre, D.; Sadaka, G. FullSWOF Paral: Comparison of two parallelization strategies (MPI and SKELGIS) on a software designed for hydrology applications. In Proceedings of the ESAIM 2013, Marseille, France, 16 July-24 August 2013; pp. 59-79.

44. Esteves, M.; Faucher, X.; Galle, S.; Vauclin, M. Overland flow and infiltration modelling for small plots during unsteady rain: Numerical results versus observed values. J. Hydrol. 2000, 228, 265-282. [CrossRef]

45. Akan, A.O. Open Channel Hydraulics, 1st ed.; Elsevier: Amsterdam, The Netherlands, 2006; p. 384.

46. Li, X.; Fang, X.; Li, J.; KC, M.; Gong, Y.; Chen, G. Estimating Time of Concentration for Overland Flow on Pervious Surfaces by Particle Tracking Method. Water 2018, 10, 379. [CrossRef]

47. Nash, J.E.; Sutcliffe, J.V. River flow forecasting through conceptual models part I-A discussion of principles. J. Hydrol. 1970, 10, 282-290. [CrossRef]

48. Fang, X.; Jiang, S.; Alam, S.R. Numerical Simulations of Efficiency of Curb-Opening Inlets. J. Hydraul. Eng. 2009, 136, 62-66. [CrossRef]

49. Chen, X. Research on classification system of urban road in Shanghai (in Chinese). Urban Transp. China 2004, 2, 39-45. 